\title{
Food Web Structure of the Alaskan Nearshore Shelf and Estuarine Lagoons of the Beaufort Sea
}

\author{
Kenneth H. Dunton • Susan V. Schonberg • \\ Lee W. Cooper
}

Received: 25 July 2011 /Revised: 20 December 2011 /Accepted: 5 January 2012/Published online: 7 February 2012

(C) The Author(s) 2012. This article is published with open access at Springerlink.com

\begin{abstract}
The eastern Alaska Beaufort Sea coast is characterized by numerous shallow ( $2-5 \mathrm{~m}$ ) estuarine lagoons, fed by streams and small rivers that drain northward from the Brooks Range through the arctic coastal plain, and bounded seaward by barrier islands and shoals. Millions of birds from six continents nest and forage during the summer period in this region using the river deltas, lagoons, and shoreline along with several species of anadromous and marine fish. We examined biogeochemical processes linking the benthic community to the overall food web structure of these poorly studied but pristine estuaries, which are largely covered by $1.8 \mathrm{~m}$ of ice for 10 months annually. In summer, these lagoons are relatively warm with brackish salinities (5$\left.10^{\circ} \mathrm{C}, S=10-25\right)$ compared to more open coastal waters $\left(0-5^{\circ} \mathrm{C}, S>27\right)$. The stable isotopic composition of organic materials in sediments (i.e., benthic particulate organic matter) and water column suspended particulate organic matter from both streams and lagoons are largely indistinguishable and reflect strong terrestrial contributions, based upon $\delta^{13} \mathrm{C}$ and $\delta^{15} \mathrm{~N}$ values $(-25.6 \%$ to $-27.4 \%$ and $1.4 \%$ to $3.3 \%$, respectively). By comparison, shifts toward more heavy isotope-enriched organic materials reflecting marine influence are observed on the adjacent coastal shelf $(-24.8 \%$ o to $-25.4 \%$ and $3.4 \%$ o to $5.3 \%$, respectively). The isotopic composition of lagoon
\end{abstract}

K. H. Dunton $(\varangle) \cdot$ S. V. Schonberg

Marine Science Institute, The University of Texas at Austin, 750 Channel View Drive,

Port Aransas, TX 78373, USA

e-mail: ken.dunton@mail.utexas.edu

L. W. Cooper

Chesapeake Biological Laboratory,

University of Maryland Center for Environmental Science,

1 Williams Street, PO Box 38, Solomons, MD 20688, USA fauna is consistent with a food web dominated by omnivorous detritovores strongly dependent on microbial processing of terrestrial sources of carbon. Biomagnification of ${ }^{15} \mathrm{~N}$ in benthic organisms indicate that the benthic food web in lagoons support up to four trophic levels, with carnivorous gastropod predators and benthic fishes $\left(\delta^{15} \mathrm{~N}\right.$ values up to $14.4 \%$ ) at the apex.

Keywords Arctic coast - Stable isotopes · Carbon . Nitrogen · Food webs · Trophic structure · Benthic community structure - Beaufort Sea - Demarcation Bay . Camden Bay $\cdot$ Estuarine lagoon $\cdot$ Climate change

\section{Introduction}

Globally, estuaries are well-recognized geomorphic features with well-established biological productivity and critical economic importance. Although less visible in the High Arctic due to 10 or more months of annual ice cover, arctic estuaries provide vital habitat for an array of organisms of enormous ecological value, which is amplified during the brief summer open-water period. In the Alaska Beaufort Sea alone, estuarine lagoons, river deltas, and bays provide feeding grounds for over 157 species of migratory birds, at least 56 of which will complete their breeding and reproductive cycle and raise their young in a matter of 6-8 weeks (Brown 2006). In addition, the band of brackish water that extends along $750 \mathrm{~km}$ of Beaufort Sea coastline provides habitat for numerous anadromous and marine fishes (e.g., arctic cisco, Coreogonus autumnalis) that are prey for foraging seals as well as local Iñupiat subsistence users of food resources (Craig 1984; von Biela et al. 2011). These fishes feed nearly exclusively on epibenthic fauna (e.g., polychaetes, mysids, and amphipods) that proliferate in the 
relatively warm summer waters of coastal bays and lagoons (Feder and Schamel 1976; Griffiths et al. 1977; Craig 1984).

The arctic estuarine environment provides distinct opportunities to explore the origin and fate of organic matter of both terrestrial and marine origin because many high latitude estuaries are free of pressures from industrial and urban development common at lower latitudes. However, these high latitude estuaries remain relatively unstudied with respect to trophic structure, the character of the benthos, the nature and magnitude of carbon inputs, the assimilation of these carbon sources, and their resilience to disturbance. Rivers export extraordinarily large amounts of organic matter to the Arctic Ocean (Dittmar and Kattner 2003; Raymond et al. 2007). For example in the Beaufort Sea, $50-75 \%$ of the carbon deposited in nearshore sediments is of terrigenous origin (Macdonald et al. 2004). Nevertheless, the importance of terrestrial carbon to nearshore arctic food webs has been debated since Schell's seminal and influential (1983) study, in which he documented (using carbon isotopes) the transfer of ancient organic $\left({ }^{14} \mathrm{C}\right.$ depleted) carbon in peat to fish and ducks in freshwater tundra ponds. The paradox however was the lack of transmission of radiocarbon-free organic molecules into the marine food web. In contrast, there are multiple examples of trophic assimilation of terrestrial carbon into temperate and subtropical estuarine food webs based on stable isotopic evidence (e.g., Sandberg et al. 2004; Barnard et al. 2006; Connolly et al. 2009). More recent studies in the eastern Alaska Beaufort Sea have also led to a more nuanced understanding of how organic carbon is transferred from land to sea. For example, arctic cod, a key, emblematic species associated with sea ice throughout the Arctic, when collected in estuarine lagoons, has tissue isotopic ratios consistent with major contributions of terrestrial organic matter (Dunton et al. 2006).

Other existing stable isotope data from the Beaufort Sea already provide some evidence of the importance of terrestrially derived particulate organic matter (POM) to marine/ estuarine food webs in the region. For example, a west to east trend in ${ }^{13} \mathrm{C}$ depletion consistent with proportionally higher terrestrial organic carbon contributions has been observed in zooplankton (Saupe et al. 1989), benthic fauna (Dunton et al. 1989), and seasonally sensitive tissues of bowhead whales that migrate through the region (Schell et al. 1989). Major inputs of ${ }^{13} \mathrm{C}$ depleted carbon from the Mackenzie River (Parsons et al. 1989) are reflected in a dramatic spatial pattern of carbon isotopic signatures in shelf sediments (Fig. 1). As noted by Macdonald et al. (2004), the depleted $\delta^{13} \mathrm{C}$ values at river mouths and along the nearshore coast suggest a strong terrestrial particulate organic carbon (POC) component that dilutes the isotopically heavier marine suspended particulate organic matter (SPOM).

Field studies along the eastern Alaska Beaufort Sea coast from 2004 to 2009 presented here provided an opportunity to examine in new detail the ecological characteristics of high arctic estuarine lagoons. Our approach emphasized the benthos and sought to address questions on faunal diversity, food web structure, carbon sources, and the fate of terrestrial organic matter. We hypothesized that carbon derived from terrestrial organic matter is assimilated by key pelagic and benthic consumers in arctic estuarine lagoons and represents an important, if not critical, organic carbon subsidy to nearshore ecosystems. The unknowns that we addressed in this study include the extent of this assimilation and the efficiency in which terrestrial POM is transferred between trophic levels. We also consider how regional climate change may affect the future functioning of estuarine lagoons. Climate-related changes in the magnitude of terrestrial inputs and inflow have an enormous potential to alter these pristine and ecologically significant geomorphic features.

\section{Beaufort Sea Coastal Waters}

The coast and shelf of the Beaufort Sea extends from Point Barrow, Alaska to Banks Island in Canada. In marked contrast to the Chukchi-Bering ecosystem to the west and the Queen Elizabeth Islands to the east, the Beaufort Sea is decidedly estuarine in character. The Mackenzie River provides the vast majority of freshwater input to the region ( $300 \mathrm{~km}^{3} /$ year), but numerous smaller rivers are also important freshwater sources (Macdonald et al. 2004; McClelland et al. 2006). Along nearly one half of the Alaskan Beaufort Sea coast, often called the North Slope, from Barrow to Demarcation Bay, an irregular and discontinuous chain of barrier islands enclose numerous shallow $(<6 \mathrm{~m})$ lagoons. Many smaller rivers discharge directly into these lagoons (Fig. 2) and are the primary source of low salinity water within the lagoons. Rivers draining the North Slope discharge peak flows of water and water-borne constituents during a several-week spring freshet (Norton and Weller 1984). Flow declines over the short summer, followed by freezing of coastal waters by early October, with ice first forming on the more sheltered and brackish lagoons and thickening throughout the winter to about $1.8 \mathrm{~m}$, becoming land fast in many shallow lagoons until breakup in late May or early June (Johnson and Richardson 1981). It is an important feature that peak freshwater discharge occurs when coastal waters are still ice covered, temporarily trapping significant amounts of terrestrial debris in the nearshore environment.

We have observed that the summer exchanges between lagoon and ocean waters of the Beaufort Sea and the magnitudes of stream inflow are extremely variable. For example, in Kaktovik Lagoon, exchange with the Beaufort Sea is limited to two very shallow $(<2.5 \mathrm{~m})$ and narrow $(25 \mathrm{~m})$ entrances. Freshwater enters the lagoon only from small tundra streams fed by small ponds and runoff from the 


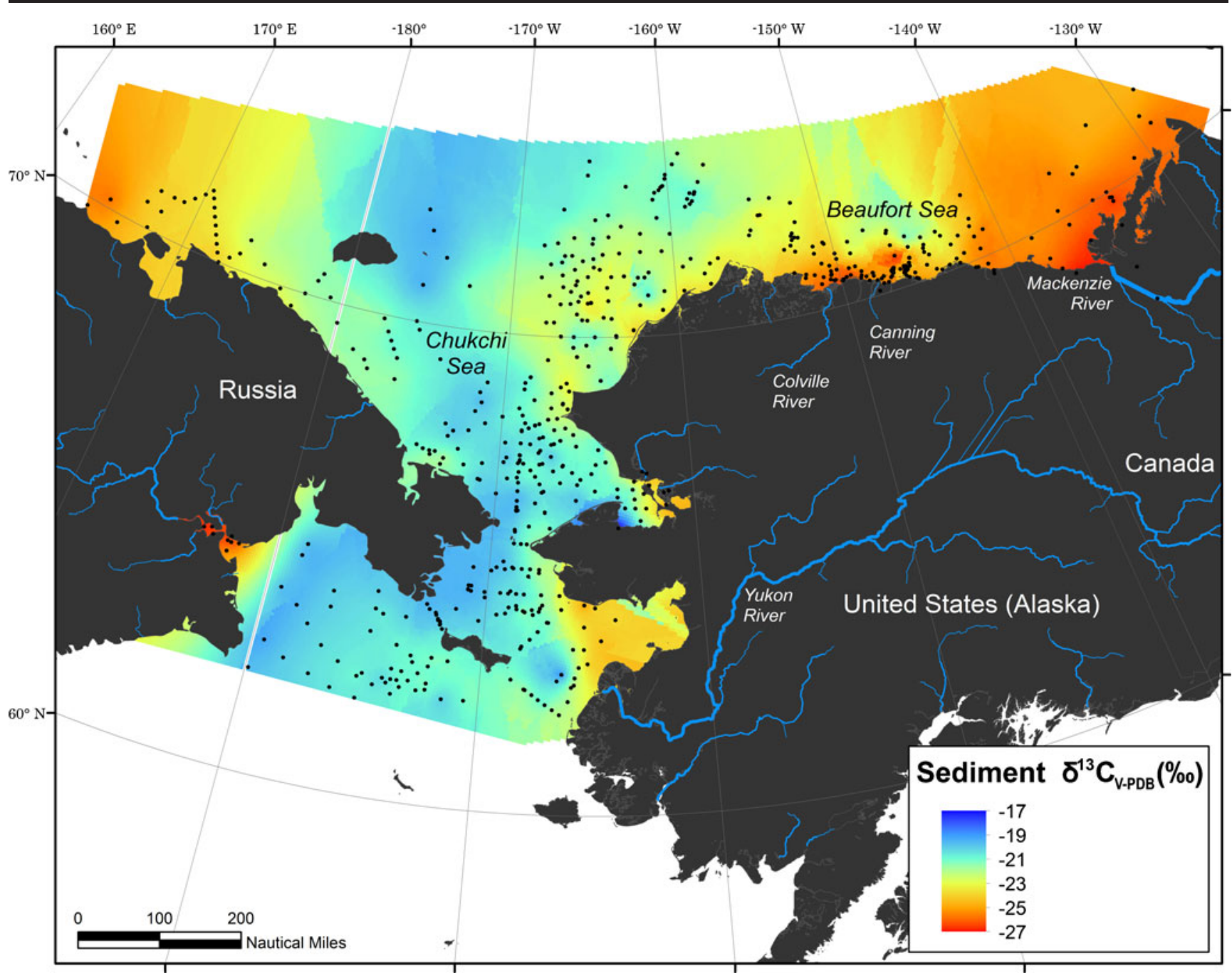

Fig. 1 The variation in the distribution of $\delta^{13} \mathrm{C}$ values for surface sediments across the western arctic coast and shelf region. The most ${ }^{13} \mathrm{C}$ depleted sediments are found at river mouths and eastward along the Beaufort Sea coast. Data from Naidu et al. (2000); Cooper et al.

surrounding tundra. In this case, no large streams flow directly into the lagoon and it is isolated from neighboring lagoons by Barter Island to the west and a peninsula to the east. In contrast, Jago Lagoon (east of Kaktovik) receives significant flow from the Jago River but exchange with the Beaufort is limited to a narrow 3-m deep channel. Several more lagoons (depth 3-4 m) of various sizes and orientation lie eastward of Kaktovik Lagoon to Demarcation Bay (Fig. 2). Another important feature of all these lagoon margins are that the landbased boundary consists of slumped 1-4 m high eroding bluffs. The shorelines, which are dominated by mixtures of sand, peat, and mud are clearly receding in most locations.

Previous biological and hydrographic investigations (Griffiths et al. 1977; Dunton and Schonberg 2006) of these lagoons show variable salinities (15-25\%) and temperatures $\left(0-10^{\circ} \mathrm{C}\right)$ during the open-water period. Due to the recessional shoreline, the seabed includes terrestrial debris. Sediments
(2002, 2009), Grebmeier et al. (2006), and this paper. GIS analysis courtesy of E. Hersh, The University of Texas at Austin (Center for Research in Water Resources)

across the shelf are generally composed of silty sands and mud with $>40 \%$ silt plus clay and support an infaunal assemblage dominated by polychaete worms, small mollusks, and crustaceans (Feder and Schamel 1976; Carey et al. 1984; Trefry et al. 2003). Along with the presence of terrestrial debris in the lagoons, the benthic biota can be remarkably diverse and abundant (Griffiths et al. 1977; Dunton and Schonberg 2000), constituting a variety of infaunal and epifaunal organisms representing nearly every major invertebrate taxon, including small sponges, polychaetes, mollusks, and ascidians. Zooplankton sampling shows that assemblages of copepods, chaetognaths, and pteropods are present in the water column. The presence of these important organisms, along with an abundance of key epibenthic prey species (polychaetes, mysids, and amphipods) for upper trophic level biota no doubt contributes to the local subsistence fishery for the village of Kaktovik. An estimated 3,000 $\mathrm{kg}$ of finfish 


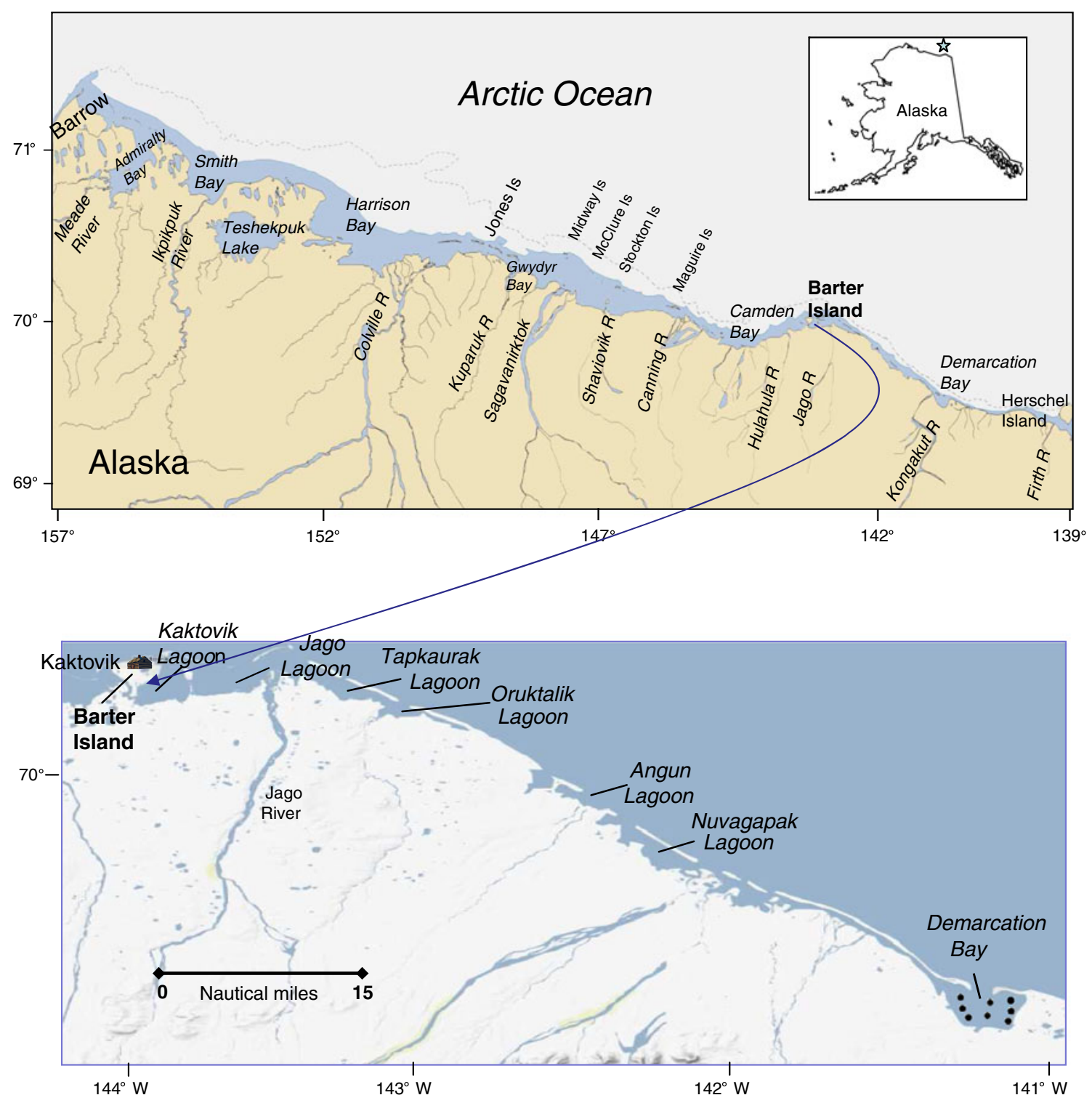

Fig. 2 The Alaska Beaufort Sea coast (top) and the linked lagoonestuarine system east of Barter Island (bottom). The majority of field collections program were conducted between Kaktovik Lagoon and

(Dolly Varden, arctic cisco) were harvested by Kaktovik residents in 1975 (Griffiths et al. 1977). Extensive subsistence fishing activities by the residents of Kaktovik continues to the present day (Dunton, personal observation).

\section{Materials and Methods}

\section{Study Area}

Our study area included (1) the open water areas on the nearshore shelf of the eastern Alaska Beaufort Sea continental shelf between Prudhoe Bay and the Canadian Border, with particular focus on Camden Bay (Fig. 2, upper panel)
Demarcation Bay in the Arctic National Wildlife Refuge. The village of Kaktovik is located on Barter Island. Quantitative sampling stations in Demarcation Bay are denoted with filled circles

and (2) within estuarine lagoons and bays enclosed by barrier islands from Kaktovik Lagoon to Demarcation Bay (Fig. 2, lower panel). We sampled within each major lagoonal system east of Barter Island, with an emphasis placed on collection of biota in the estuarine lagoons. Sampling took place in summers 2008 and 2009 using the vessels Arctic Seal and Alpha Helix for offshore sampling, and in summers 2004, 2007, and 2008 using the Proteus for lagoon and estuarine studies.

Biota

Benthic infaunal organisms were sampled using replicate $0.1 \mathrm{~m}^{2}$ double van Veen grab (offshore waters) and a 
$0.023 \mathrm{~m}^{2}$ Ekman grab (shallow lagoons). A 1-m beam trawl fitted with a 1-mm mesh size net was used to collect epifauna. We used valid species names and feeding classification schemes according to the World Register of Marine Species (http://www.marinespecies.org) and Macdonald et al. (2010). For water column biota, plankton nets (mesh size, $20 \mu$ and $335 \mu$ ) were deployed from the vessel and pulled obliquely through the water column. Invertebrates were carefully washed over a $1.0 \mathrm{~mm}$ sieve, sorted, identified to the species level and processed for isotopic or quantitative analyses in the field. Net $335 \mu$ plankton samples were sorted under a dissecting scope to remove any large debris and then concentrated onto precombusted $\left(450^{\circ} \mathrm{C}\right.$ for $\left.8 \mathrm{~h}\right)$ Whatman $\mathrm{GF} / \mathrm{F}$ filters for isotopic analysis. Similarly, net $20 \mu$ plankton samples were concentrated onto precombusted Whatman GF/F filters following collection. Benthic biota for quantitative analysis were weighed on a microbalance and preserved in $80 \%$ ethanol; otherwise samples were dried at $60^{\circ} \mathrm{C}$ and weighed (to the nearest $1.0 \times 10^{-6} \mathrm{~g}$ ) and stored in screw cap vials for stable isotope analysis. Isotopic analysis of SPOM was accomplished through filtration of water collected using a van Dorn bottle at $2 \mathrm{~m}$ depth in the lagoons, and in Camden Bay, from shallow $(5 \mathrm{~m})$, intermediate $(10 \mathrm{~m})$, and near-bottom depths $(25 \mathrm{~m})$ onto precombusted Whatman GF/F filters. SPOM filters were stored in the dark prior to arrival for analysis at The University of Texas Marine Science Institute (UTMSI) for elemental analysis.

All organic samples for isotopic analysis were dried in aluminum dishes or glass vials at $60^{\circ} \mathrm{C}$ following removal of extraneous organic matter. When possible, soft tissues were removed from shelled organisms, but all invertebrate samples were subsequently soaked in $1 \mathrm{~N}$ $\mathrm{HCl}$ for several hours (or until bubbling stopped) to remove carbonates, rinsed in distilled water, and then dried. Only muscle or body wall tissue was analyzed from bivalves, gastropods, large crustaceans (euphausiids and amphipods), and fish; all other organisms were analyzed whole. Entire organisms or tissues were manually ground for isotopic analyses. Replicate analyses reflect the analysis of individual organisms, not composite samples. All $\delta^{13} \mathrm{C}$ and $\delta^{15} \mathrm{~N}$ measurements were made using a Finnigan MAT Delta Plus stable isotope mass spectrometer coupled to an elemental analyzer at UTMSI (elemental analyzer was a CE Instruments, NC 2500) or on a DeltaV in the stable isotope laboratory at the University of Alaska Fairbanks (elemental analyzer was a Costech ESC 4010). In general, samples were combusted at $1,020^{\circ} \mathrm{C}$ and the resulting purified nitrogen and carbon dioxide was then passed into the mass spectrometer with a continuous carrier stream of ultrahigh purity helium. Results are expressed in standard $\delta$ notation relative to carbonate Vienna-PeeDee Belemnite and atmospheric nitrogen where:

$\delta^{13} \mathrm{C} \quad$ or $\left.\quad \delta^{15} \mathrm{~N}(\% o)=\left[\mathrm{R}_{\text {sample }} / \mathrm{R}_{\text {standard }}\right)-1\right] \times 1000$

and $R=\left({ }^{13} \mathrm{C} /{ }^{12} \mathrm{C}\right.$ or $\left.{ }^{15} \mathrm{~N} /{ }^{14} \mathrm{~N}\right)$, respectively. Instrumental analytical error was $\pm 0.15 \%$ and analytical sample error was $\pm 0.2 \%$, based upon internal standards. Accuracy was assured by referencing tank reference gasses to internal standards from the US National Institute of Science and Technology and the International Atomic Energy Agency.

\section{Water Column Parameters}

Temperature, salinity, and $\mathrm{pH}$ were measured using YSI 600 XLM Data Sonde (YSI Inc., Yellow Springs, OH, USA). Two replicate water samples were collected for macronutrient analysis in the lagoons at 2-m depths using a van Dorn bottle. All samples were placed in prelabeled plastic bottles and sampling point geographic coordinates (latitude/longitude) were recorded using a handheld Garmin Global Positioning System, GPSMap 76S (Garmin International Inc., Olathe, KS, USA). Samples were frozen and stored in a freezer prior to overnight shipping to UTMSI for nutrient analysis. Nutrient concentrations for $\mathrm{NH}_{4}{ }^{+}, \mathrm{PO}_{4}{ }^{3-}, \mathrm{SiO}_{4}$, and $\mathrm{NO}_{2}{ }^{-}+\mathrm{NO}_{3}{ }^{-}$, were determined using colorimetric techniques on a Lachat QuikChem 8000 (Zellweger Analytics Inc., Milwaukee, WI, USA) with a minimum detection level of $0.03 \mu \mathrm{M}$.

Water column chlorophyll concentrations (in Camden Bay) were determined from two replicate $100-\mathrm{ml}$ water samples filtered through a $0.45 \mu \mathrm{m}$ cellulose nitrate membrane filter (Whatman, Maidstone, England) in darkness. After filtration, the filters and residue were placed in prelabeled opaque vials, frozen and transported to UTMSI for chlorophyll analysis. Filters were then placed in prelabeled test tubes containing $5 \mathrm{ml}$ of $90 \%$ acetone for overnight extraction (Parsons et al. 1984). Chlorophyll $a$ concentration, in microgram per liter, was determined using a Shimadzu UV-2401 PC spectrophotometer by measuring absorbance at wavelengths 750,664 , 647, 630, and $600 \mathrm{~nm}$.

Water transparency, as reflected by the diffuse attenuation coefficient $(k)$ was calculated from measurements of photosynethically active radiation (PAR) collected using LI-192SA underwater cosine sensors connected to a LI-1000 datalogger (LI-COR Inc., Lincoln, NE, USA). The sensors were mounted on a lowering frame and light measurements recorded at the surface, 2-, and 4-m depths. Care was taken to avoid interference from shading of the sensor by the vessel.

\section{Trophic Level Determinations}

Isotopic differences among particulate organic carbon and sediment sources collected in rivers, lagoons and on the 
mid-shelf (Camden Bay) were analyzed separately using a one-way analysis of variance (ANOVA). Post hoc comparisons of means were performed using a two-way ANOVA with a pairwise comparison with significant differences determined at $\alpha<0.05$. Trophic levels were determined from isotopic values using the trophic enrichment equation of Iken et al. (2010):

$$
\mathrm{TL}(\mathrm{POM})=\left(\delta^{15} \mathrm{~N}_{\text {consumer }}-\delta^{15} \mathrm{~N}_{\mathrm{POM}}\right) / 3.4+1
$$

where, 3.4 is the average per mille enrichment in $\delta^{15} \mathrm{~N}$ between successive trophic levels (TL) using POM as the ultimate trophic carbon source. We recognize in using 3.4\%o that there is some variation in the appropriate enrichment per trophic level in different ecosystems, including the ecosystem studied here. For example, in the Antarctic Peninsula, Dunton (2001) used a value of 3.2\%o per trophic level, which is comparable to values of 3.3\% applied by Wada et al. (1987) to the Southern Ocean and Rau et al. (1992) in the northeast Atlantic. In the Alaskan Arctic, Iken et al. (2010) used a 3.4\%o enrichment based on the extensive reviews of the topic by Vander Zanden and Rasmussen (2001) and Post (2002), which identified 3.4\% as an average isotopic fractionation for aquatic consumers.

In recognition that trophic increases are variable between consumers and their source material, we introduced mixing lines that delimited the isotopic value ranges expected for the transfer of ${ }^{13} \mathrm{C}$ or ${ }^{15} \mathrm{~N}$ through the food web. For example, in this study, selective and nonselective filter feeders such as bryozoans and ascidians had $\delta^{13} \mathrm{C}$ and $\delta^{15} \mathrm{~N}$ enrichments up to $1.9 \%$ and $3.8 \%$, respectively, compared to lagoon SPOM. In other cases, $\delta^{13} \mathrm{C}$ and $\delta^{15} \mathrm{~N}$ enrichments of primary consumers (such as the filter feeding bivalve Macoma calcarea on the coastal shelf) were limited to $0.8 \%$ and $2.4 \%$ relative to shelf SPOM. Schell et al. (1998) noted average $\delta^{13} \mathrm{C}$ and $\delta^{15} \mathrm{~N}$ enrichments of about $1.3 \%$ and $2.5 \%$ between chaetognaths, which feed exclusively on calanoid copepods from in the western arctic. In recognition of this variability, we used two conservative mixing lines to best assess the relative importance and role of the lagoon SPOM and river sediment (or benthic POM, BPOM) sources available to consumers on $\delta^{13} \mathrm{C}$ vs $\delta^{15} \mathrm{~N}$ bi-plots. In this approach, also used by Darnaude et al. (2004), two mixing lines are constructed that potentially correspond to minimum and maximum trophic increases of $+1.0 \%$ and $+2.0 \%$ in $\delta^{13} \mathrm{C}$ and maximum and minimum trophic increases of $+4.0 \%$ and $+2.5 \%$ in $\delta^{15} \mathrm{~N}$ per trophic level. These two potential combinations of the range of trophic level enrichment for both carbon and nitrogen isotope values result in positive slopes of 1.25 and 4 from the source material (lagoon SPOM for pelagic grazers and benthic filter feeders; river BPOM for deposit/subsurface feeders, and both lagoon SPOM and river BPOM for omnivorous detritovores). These mixing lines provide a boundary and a mechanistic tool to assess the dependence of consumers on the suspected ultimate carbon sources. Our selection of river BPOM and lagoon SPOM as carbon and nitrogen end-members for epibenthic lagoon biota was largely based on the opportunistic and omnivorous feeding strategies employed by most arctic fauna (Dunton and Schell 1987; Iken et al. 2010).

\section{Results}

The Physical and Chemical Environment

The hydrography of the inshore lagoons of the eastern Beaufort Sea coast is notably estuarine (Table 1) in comparison to the open water coastal sites (e.g., Bernard Point and Demarcation Point) and the mid-shelf (Camden Bay). Salinities across the lagoons ranged from about 15 to 27 compared to nearly 30 on the nearshore shelf. By midAugust, water temperatures in the lagoons had also warmed to as much as $6-11^{\circ} \mathrm{C}$ in comparison to immediate open coastal areas, which remained less than $2^{\circ} \mathrm{C}$. Lagoon waters also had high transparency by August, reflecting low freshwater inputs of POM and color-dissolved organic materials into the lagoons following the spring freshet (McClelland et al. 2011).

Inorganic-N concentrations were very low for all site locations. Concentrations of ammonium and nitrate + nitrite in surface $(2 \mathrm{~m})$ samples from Camden Bay seldom exceeded $0.5 \mu \mathrm{M}$ for $\mathrm{NH}_{4}{ }^{+}$or $\mathrm{NO}_{2}{ }^{-}+\mathrm{NO}_{3}{ }^{-}$(Table 2), with water column chlorophyll levels ranging from undetectable to $0.5 \mu \mathrm{g} \mathrm{L}^{-1}$ (data not shown). Similar low, inorganic-N concentrations were observed in the lagoons; in many lagoons, ammonium was the dominant inorganic nitrogen species, suggesting significant sedimentary recycling (Table 2). Concentrations of inorganic phosphate and silica were variable, both offshore and in the lagoons. Higher silica concentrations in some lagoons may reflect local riverine sources.

\section{Lagoon Benthic Community Structure}

Benthic infaunal populations within Demarcation Bay were analyzed at eight stations, all ranging in depth from 4 to $5 \mathrm{~m}$ and distributed evenly across the bay (Fig. 2). We collected a total of 48 species distributed among eight invertebrate phyla. Polychaetes, mollusks, and crustaceans constituted a major fraction of the total faunal abundance and biomass (Table 3). Species richness was greatest for polychaetes (22), followed by molluscs (10) and amphipods (6). Hydroids and bryozoans that attach to pebbles or rocks were collected in small numbers along with one species from each of the ascidian, foraminifera, and priapulid taxa. Total 
Table 1 Hydrographic and chemical features of the eastern Beaufort Sea coast in August derived from surface measurements

\begin{tabular}{|c|c|c|c|c|c|}
\hline Location & $\mathrm{pH}$ & Light Attenuation $\left(k, \mathrm{~m}^{-1}\right)$ & Temperature $\left({ }^{\circ} \mathrm{C}\right)$ & Salinity (\%o) & Depth (m) \\
\hline Camden Bay, Beaufort Sea $\left(145^{\circ} \mathrm{W}\right)$ & 8.1 & nd & 5.4 & 27.1 & 32.1 \\
\hline Kaktovik Lagoon & 8.1 & 1.1 & 7.1 & 23.3 & 4.5 \\
\hline Bernard Point, Beaufort Sea $\left(144^{\circ} \mathrm{W}\right)$ & 8.2 & 0.5 & 0.4 & 29.5 & 10.0 \\
\hline Tapkaurak Lagoon & 8.2 & 1.0 & 5.9 & 25.0 & 2.5 \\
\hline Oruktalik Lagoon & 8.2 & 1.0 & 3.6 & 27.4 & 2.5 \\
\hline Angun Lagoon & 8.2 & 0.8 & 2.7 & 14.6 & 2.5 \\
\hline Nuvagapak Lagoon & 8.2 & 0.6 & 11.1 & 16.0 & 2.5 \\
\hline Demarcation Bay & 8.2 & 0.8 & 3.3 & 27.5 & 4.0 \\
\hline Demarcation Point $\left(141^{\circ} \mathrm{W}\right)$ & nd & 0.7 & 1.8 & 29.6 & 6.0 \\
\hline
\end{tabular}

Values recorded in Camden Bay on the nearshore shelf are from August 2008; all other measurements are from August 2004

nd not determined

mean biomass was $35 \mathrm{~g}$ wet weight per square meter and abundance of 951 individuals per square meter.

\section{Sources of Organic Carbon}

Our isotopic measurements of SPOM and BPOM from a variety of geographic locations indicate the presence of two major categories of organic matter on the Beaufort Sea coastal shelf. A distinct terrestrial source has lower $\delta^{13} \mathrm{C}$ and $\delta^{15} \mathrm{~N}$ values (Table 4) while marine organic materials are more isotopically enriched in both ${ }^{13} \mathrm{C}$ and ${ }^{15} \mathrm{~N}$ (Table 5). There were no significant differences $(p>0.05)$ in ${ }^{13} \mathrm{C}$ or ${ }^{15} \mathrm{~N}$ isotopic values between river BPOM and SPOM, or between lagoon BPOM and SPOM. However, shelf BPOM and SPOM were significantly different from each other for both ${ }^{13} \mathrm{C}(p=0.02)$ and ${ }^{15} \mathrm{~N}(p<0.0001)$, possibly due to seasonally integrated inventories for BPOM vs. snap shot sampling for SPOM (Lovvorn et al. 2005; Morata et al. 2008). Our analyses also indicated that for SPOM, isotopic sources of carbon and nitrogen from rivers and lagoons differed significantly from shelves $(p<0.02)$.
The terrestrial inputs of organic matter from rivers were well constrained by $\delta^{15} \mathrm{~N}$ and $\delta^{13} \mathrm{C}$ values of $1.7 \%$ and $-25.6 \%$ for BPOM and $1.4 \%$ and $-27.3 \%$ for SPOM, respectively. In contrast, the $\delta^{15} \mathrm{~N}$ and $\delta^{13} \mathrm{C}$ values for more marine influenced BPOM from Camden Bay were 3.4\% and $-25.4 \%$, with SPOM averaging 5.3\%o and $-24.8 \%$, respectively. Interestingly, lagoon BPOM and SPOM for $\delta^{15} \mathrm{~N}$ tended to approach shelf values (3.0-3.3\%o), while lagoon $\delta^{13} \mathrm{C}$ remained closer to river SPOM values $(-27.4 \%$ to $-26.1 \%$ ).

These source SPOM values are also consistent with the isotopic composition of primary consumers. For example, in the lagoons, both the ascidian Molgula griffithsii, a nonselective suspension feeder, and the bryozoan Eucratea loricata, which feeds exclusively on phytoplankton (Winston 1977), had $\delta^{15} \mathrm{~N}$ and $\delta^{13} \mathrm{C}$ values that closely matched a first level trophic enrichment from SPOM at 6.8 and $-25.9 \%$, respectively (Fig. 3, top panel). The enrichment relative to lagoon SPOM was $+3.8 \%$ for nitrogen and $+1.5 \%$ for carbon. The $\delta^{15} \mathrm{~N}$ values of lower trophic benthic-dwelling crustaceans that live directly within and on the sediments,

Table 2 Inorganic concentrations of nitrogen, phosphorus, and silicate based on two replicate water samples collected at $2 \mathrm{~m}$ depths at specific sites along the eastern Beaufort Sea coast in August 2004

\begin{tabular}{|c|c|c|c|c|}
\hline Location & Ammonium $\mathrm{NH}_{4}^{+}(\mu \mathrm{M})$ & $\begin{array}{l}\text { Nitrate+Nitrite } \\
\mathrm{NO}^{2-}+\mathrm{NO}^{3-}(\mu \mathrm{M})\end{array}$ & Phosphate $\mathrm{PO}_{4}{ }^{3-}(\mu \mathrm{M})$ & Silicate $\mathrm{SiO}_{4}(\mu \mathrm{M})$ \\
\hline Camden Bay, Beaufort Sea $\left(145^{\circ} \mathrm{W}\right)$ & 0.40 & 0.05 & 0.25 & 4.50 \\
\hline Kaktovik Lagoon & 0.22 & 0.59 & 0.21 & 2.99 \\
\hline Bernard Point, Beaufort Sea $\left(144^{\circ} \mathrm{W}\right)$ & 0.22 & 0.07 & 0.45 & 1.06 \\
\hline Tapkaurak Lagoon & 0.68 & 0.13 & 0.39 & 2.07 \\
\hline Oruktalik Lagoon & 0.42 & 0.17 & 0.38 & 1.66 \\
\hline Angun Lagoon & 0.60 & 0.17 & 0.41 & 1.99 \\
\hline Nuvagapak Lagoon & 0.25 & 0.10 & 0.16 & 6.88 \\
\hline Demarcation Bay & 0.14 & 2.29 & 0.43 & 0.43 \\
\hline
\end{tabular}

Nutrient levels from Camden Bay were determined from eight samples collected in August 2008 at $2 \mathrm{~m}$ 
Table 3 The benthic phyla of Demarcation Bay, including measurements of density (number per square meter) and wet weight biomass (grams per square meter) based on quantitative grab samples collected at eight stations (number of grabs=14) in August 2008

\begin{tabular}{|c|c|c|c|c|c|c|}
\hline Taxonomic group & Number of species & $n$ & $\mathrm{n} \mathrm{m}^{-2} \pm \mathrm{SE}$ & $\%$ total $\mathrm{n} \mathrm{m}^{-2}$ & g wet wt $\mathrm{m}^{-2} \pm \mathrm{SE}$ & $\%$ total $\mathrm{g}$ wet wt $\mathrm{m}^{-2}$ \\
\hline Foraminifera & 1 & 2 & $86.1 \pm 64.6$ & 9 & $0.4 \pm 0.3$ & 1 \\
\hline Hydrozoa & 2 & 3 & nd & nd & $0.3 \pm 0.0$ & $<1$ \\
\hline \multicolumn{7}{|l|}{ Annelida } \\
\hline Polychaeta & 22 & 63 & $194.8 \pm 38.6$ & 20 & $2.5 \pm 0.7$ & 7 \\
\hline \multicolumn{7}{|l|}{ Mollusca } \\
\hline Gastropoda & 5 & 12 & $175.8 \pm 67.0$ & 18 & $1.6 \pm 0.6$ & 5 \\
\hline Nudibranchia & 1 & 2 & $32.3 \pm 10.8$ & 3 & $0.4 \pm 0.3$ & 1 \\
\hline Bivalvia & 4 & 14 & $101.5 \pm 20.0$ & 11 & $10.4 \pm 2.6$ & 30 \\
\hline \multicolumn{7}{|l|}{ Crustacea } \\
\hline Mysid & 1 & 1 & 21.5 & 2 & 0.2 & $<1$ \\
\hline Amphipoda & 6 & 9 & $62.2 \pm 21.1$ & 7 & $1.8 \pm 0.8$ & 5 \\
\hline Cumacea & 1 & 2 & $129.2 \pm 64.6$ & 14 & $0.9 \pm 0.4$ & 3 \\
\hline Isopoda & 1 & 2 & $43.1 \pm 21.5$ & 5 & $5.0 \pm 0.2$ & 14 \\
\hline Priapulid & 1 & 7 & $83.0 \pm 15.2$ & 9 & $3.6 \pm 1.8$ & 10 \\
\hline Bryozoa & 3 & 8 & nd & nd & $6.5 \pm 3.3$ & 19 \\
\hline Ascidian & 1 & 2 & $21.5 \pm 0.0$ & 2 & $1.3 \pm 0.0$ & 4 \\
\hline
\end{tabular}

$n d$ not determined

such as the amphipods Pontoporeia femorata (5.2\%) and Monoculodes (3.7\%o), approximated a first level tropic enrichment from river SPOM/BPOM of about 3.0\%. For the inner shelf of the coastal Beaufort Sea, the $\delta^{15} \mathrm{~N}$ values of grazers and filter feeders, including calanoid copepods (9.8\%) and the bivalve Liocyma fluctuosa (7.6\%), matched the expected one trophic level enrichment from SPOM $(5.3 \%$ ) of roughly $3.4 \%$ (Fig. 4 ).

\section{Isotopic Signatures of Pelagic and Benthic Biota}

The nearly 60 species of pelagic and benthic organisms in lagoons and coastal shelf habitats analyzed in this study included 11 invertebrate phyla, six species of fish, and two mammals (Tables 4 and 5). As expected, the carbon and nitrogen isotopic ratios of this biota varied substantially, reflecting known feeding strategies and geographic location. Based upon these known feeding strategies, consumers were separated into one of three trophic guilds (Fig. 3). These guilds were: (1) pelagic grazers (copepods, chaetognaths, arctic cod) and filter/suspension feeders (hydroids, bryozoans, and ascidians); (2) epibenthic organisms that are largely omnivorous and feed at the sediment-water column interface, including various polychaetes (Nicolea, Terebellides), amphipods (Anonyx), mysids, gastropods (Buccinum), bivalves (Macoma), blennies and sculpins; and (3) deposit and subsurface feeders. The deposit feeders included infaunal organisms that either ingest and assimilate large volumes of sediment and detritus or their predators, such as various gastropods (Cryptonatica, Euspira), bivalves (Portlandia,
Yoldia), predatory amphipods (Monoculodes), ribbon worms, and polychaetes (scaleworms).

One complexity to using faunal $\delta^{13} \mathrm{C}$ values to assess consumer dependence on ultimate carbon sources is that ${ }^{13} \mathrm{C}$ is relatively more depleted in lipids, so for organisms with high lipid content, misleading conclusions about carbon sources are possible (Post et al. 2007). We used the Post et al. (2007) approach to evaluate this question by examining the relationship between consumer $\delta^{13} \mathrm{C}$ values and $\mathrm{C} / \mathrm{N}$ ratios within our data (Tables 4 and 5). Post et al. (2007) found that the $\mathrm{C} / \mathrm{N}$ ratio can be a strong proxy for lipid content in both aquatic and terrestrial animals, but our data show no apparent relationship $(n=55, r=0.005, p=0.98)$ between $\mathrm{C} / \mathrm{N}$ ratios and $\delta^{13} \mathrm{C}$ values of consumers (Fig. 5). The lack of correlation between $\delta^{13} \mathrm{C}$ values and $\mathrm{C} / \mathrm{N}$ ratios suggests that few if any of the organisms studied have carbon isotope composition affected by high lipid content; we therefore did not attempt to correct measured carbon isotope composition based upon $\mathrm{C} / \mathrm{N}$ ratios (Post et al. 2007). These conclusions are consistent with other high-latitude studies (e.g., Dunton 2001; Iken et al. 2010) that also did not require lipid normalization to identify organic carbon sources.

Our selection of end-member carbon and nitrogen sources for the eastern Beaufort estuarine lagoon ecosystem (Table 4) largely incorporated the organisms we collected in both the water column and sediments. Moreover, our choice of river BPOM as a terrestrial end-member was consistent with $\delta^{15} \mathrm{~N}$ and $\delta^{13} \mathrm{C}$ values of $2.0 \%$ and $-25.1 \%$ for a first-order grazing mammal (Rangifer tarandus, caribou) that feeds on fresh terrestrial plant matter (Table 4). The caribou's isotopic 
Table $4 \delta^{13} \mathrm{C}$ and $\delta^{15} \mathrm{~N}$ values (mean $\pm \mathrm{SE}$ ) and molar $\mathrm{C} / \mathrm{N}$ ratios (mean $\pm \mathrm{SE}(n)$ ) of BPOM from sediments (six rivers and three lagoons), SPOM (four rivers and three lagoons), and biota collected in several lagoons along the eastern Beaufort Sea coast in August 2004, 2007, and 2008

\begin{tabular}{|c|c|c|c|c|c|}
\hline Species or group & $n$ & $\delta^{15} \mathrm{~N}(\%)$ & $\delta^{13} \mathrm{C}(\%)$ & $\mathrm{C} / \mathrm{N}$ (moles/mole) & Fig \\
\hline \multicolumn{6}{|l|}{ Sources of organic matter } \\
\hline River BPOM & 6 & $1.7 \pm 0.2$ & $-25.6 \pm 0.2$ & nd & \\
\hline River SPOM & 4 & $1.4 \pm 0.2$ & $-27.3 \pm 0.3$ & nd & \\
\hline Lagoon BPOM & 3 & $3.3 \pm 0.8$ & $-26.1 \pm 0.4$ & nd & \\
\hline Lagoon SPOM & 15 & $3.0 \pm 0.7$ & $-27.4 \pm 0.3$ & nd & \\
\hline \multicolumn{6}{|l|}{ Invertebrate consumers } \\
\hline \multicolumn{6}{|l|}{ Cnidaria } \\
\hline \multicolumn{6}{|l|}{ Hydrozoa (hydroids) } \\
\hline Obelia longissima & 2 & $7.0 \pm 0.7$ & $-24.5 \pm 0.2$ & $2.9 \pm 0.3(2)$ & 1 \\
\hline \multicolumn{6}{|l|}{ Ctenophora } \\
\hline Ctenophore & 1 & 12.4 & -24.9 & nd & 2 \\
\hline \multicolumn{6}{|l|}{ Cephaloryncha } \\
\hline Priapulus caudatus & 6 & $12.5 \pm 0.3$ & $-21.4 \pm 0.4$ & $3.7 \pm 0.1(6)$ & 3 \\
\hline \multicolumn{6}{|l|}{ Chaetognatha } \\
\hline Sagitta sp. & 3 & $14.8 \pm 0.3$ & $-23.3 \pm 0.2$ & nd & 4 \\
\hline \multicolumn{6}{|l|}{ Sipuncula } \\
\hline Sipunculid (peanut worms) & 1 & 11.9 & -17.9 & $3.6(1)$ & 5 \\
\hline \multicolumn{6}{|l|}{ Nemertea } \\
\hline Nemertean (ribbon worms) & 1 & 11.8 & -21.3 & $4.0(1)$ & 6 \\
\hline \multicolumn{6}{|l|}{ Annelida } \\
\hline \multicolumn{6}{|l|}{ Polychaeta } \\
\hline Nephtys sp. & 1 & 11.3 & -19.8 & $3.5(1)$ & 7 \\
\hline Nereimyra aphroditoides & 4 & $10.8 \pm 0.3$ & $-20.7 \pm 0.3$ & $4.5 \pm 0.1(4)$ & 8 \\
\hline Nicolea zostericola & 12 & $8.6 \pm 0.2$ & $-23.6 \pm 0.3$ & $4.1 \pm 0.1(9)$ & 9 \\
\hline Potamilla neglecta & 6 & $8.4 \pm 0.2$ & $-24.3 \pm 0.3$ & $3.8 \pm 0.1(6)$ & 10 \\
\hline Prionospio cirrifera & 7 & $9.9 \pm 0.2$ & $-22.1 \pm 0.1$ & $3.8 \pm 0.2(3)$ & 11 \\
\hline Sabellidae (feather duster worms) & 1 & 8.4 & -24.7 & $4.1(1)$ & 12 \\
\hline Polynoidae (scaleworms) & 7 & $10.5 \pm 0.4$ & $-22.2 \pm 0.4$ & $3.3 \pm 0.4(5)$ & 13 \\
\hline Spio filicornis & 3 & $8.1 \pm 0.6$ & $-22.3 \pm 0.4$ & nd & 14 \\
\hline Terebellides stroemi & 17 & $9.1 \pm 0.2$ & $-23.8 \pm 0.2$ & $3.4 \pm 0.2(13)$ & 15 \\
\hline Travisia forbesii & 1 & 11.2 & -22.9 & $4.1(1)$ & 16 \\
\hline \multicolumn{6}{|l|}{ Mollusca } \\
\hline \multicolumn{6}{|l|}{ Gastropoda } \\
\hline Boreocingula martyni & 3 & $7.5 \pm 0.2$ & $-20.7 \pm 0.4$ & $3.3 \pm 0.6(3)$ & 17 \\
\hline Buccinum sp. & 1 & 14.4 & -19.5 & $3.7(1)$ & 18 \\
\hline Cryptonatica affinis & 1 & 11.0 & -18.3 & $3.9(1)$ & 19 \\
\hline Cylichna occulta & 11 & $10.2 \pm 0.5$ & $-19.6 \pm 0.5$ & $3.7 \pm 0.3(11)$ & 20 \\
\hline Euspira pallida & 2 & $12.1 \pm 0.7$ & $-21.7 \pm 1.4$ & nd & 21 \\
\hline \multicolumn{6}{|l|}{ Bivalvia } \\
\hline Astarte borealis & 1 & 7.9 & -24.8 & $3.6(1)$ & 22 \\
\hline Cyrtodaria kurriana & 4 & $7.9 \pm 0.1$ & $-25.2 \pm 0.1$ & $3.4 \pm 0.3(4)$ & 23 \\
\hline Liocyma fluctuosa & 14 & $8.3 \pm 0.3$ & $-25.4 \pm 0.2$ & $4.1 \pm 0.1(11)$ & 24 \\
\hline Macoma sp. & 1 & 7.6 & $-23.5 \pm$ & $3.9(1)$ & 25 \\
\hline Portlandia arctica & 1 & 8.5 & -23.3 & $3.7(1)$ & 26 \\
\hline Yoldia myalis & 16 & $7.5 \pm 0.4$ & $-21.2 \pm 0.3$ & $3.1 \pm 0.2(16)$ & 27 \\
\hline \multicolumn{6}{|l|}{ Arthropoda } \\
\hline \multicolumn{6}{|l|}{ Crustacea } \\
\hline Anonyx nugax $<10 \mathrm{~mm}$ & 6 & $9.5 \pm 0.1$ & $-21.5 \pm 0.2$ & $4.1 \pm 0.2(6)$ & 28 \\
\hline
\end{tabular}


Table 4 (continued)

\begin{tabular}{|c|c|c|c|c|c|}
\hline Species or group & $n$ & $\delta^{15} \mathrm{~N}(\%)$ & $\delta^{13} \mathrm{C}(\%)$ & $\mathrm{C} / \mathrm{N}($ moles $/$ mole $)$ & Fig.3 Label \\
\hline Anonyx nugax $>10 \mathrm{~mm}$ & 8 & $13.3 \pm 0.3$ & $-22.2 \pm 0.4$ & $4.5 \pm 0.1(2)$ & 29 \\
\hline Atylus carinatus & 15 & $7.3 \pm 0.4$ & $-22.6 \pm 0.3$ & $3.4 \pm 1(2)$ & 30 \\
\hline Calanus hyperboreus & 5 & $9.9 \pm 0.4$ & $-24.3 \pm 0.4$ & $4.4 \pm 0.3(5)$ & 31 \\
\hline Calanoid copepods & 19 & $9.5 \pm 0.5$ & $-25.3 \pm 0.3$ & nd & 31 \\
\hline Diastylis sp. & 4 & $6.6 \pm 0.2$ & $-23.1 \pm 0.2$ & $3.8 \pm 0.2(4)$ & 32 \\
\hline Gammaracanthus loricatus & 8 & $10.1 \pm 0.3$ & $-21.7 \pm 0.3$ & $3.9 \pm 0.2(2)$ & 33 \\
\hline Gammarus setosus & 17 & $6.6 \pm 0.6$ & $-23.4 \pm 0.3$ & $4.0 \pm 0.2(11)$ & 34 \\
\hline Monoculodes sp. & 1 & 3.7 & -23.1 & nd & 35 \\
\hline Mysis sp. & 35 & $7.9 \pm 0.3$ & $-21.9 \pm 0.2$ & $3.8 \pm 0.1(27)$ & 36 \\
\hline Plankton (from $335 \mu$ net) & 4 & $9.6 \pm 0.1$ & $-25.9 \pm 0.3$ & nd & 37 \\
\hline Plankton (from $20 \mu$ net) & 2 & $8.5 \pm 0.5$ & $-26.0 \pm 0.2$ & nd & 38 \\
\hline Pontoporeia femorata & 2 & $5.2 \pm 0.2$ & $-22.5 \pm 0.1$ & $4.5 \pm 0.1(2)$ & 39 \\
\hline Saduria entomon & 12 & $8.6 \pm 1.0$ & $-21.0 \pm 0.3$ & $3.2 \pm 0.2(12)$ & 40 \\
\hline \multicolumn{6}{|l|}{ Bryozoa } \\
\hline Alcyonidium disciforme & 9 & $6.8 \pm 0.5$ & $-24.7 \pm 0.3$ & $1.5 \pm 0.1(7)$ & 41 \\
\hline Eucratea loricata & 9 & $6.8 \pm 0.5$ & $-26.1 \pm 0.3$ & $2.2 \pm 0.2(9)$ & 42 \\
\hline \multicolumn{6}{|l|}{ Urochordata } \\
\hline Molgula griffithsii & 6 & $6.8 \pm 0.3$ & $-25.7 \pm 0.2$ & $2.2 \pm 0.2(6)$ & 43 \\
\hline \multicolumn{6}{|l|}{ Vertebrate consumers } \\
\hline \multicolumn{6}{|l|}{ Vertebrata } \\
\hline \multicolumn{6}{|l|}{ Osteichthyes } \\
\hline Boreogadus saida & 7 & $12.2 \pm 0.4$ & $-24.7 \pm 0.5$ & $4.5 \pm 0.2(9)$ & 44 \\
\hline Lumpenus fabricii & 16 & $12.3 \pm 0.2$ & $-23.0 \pm 0.2$ & $3.8 \pm 0.1(16)$ & 45 \\
\hline Lycodes sp. & 2 & $14.3 \pm 0.1$ & $-20.1 \pm 0.3$ & $4.5 \pm 0.1(2)$ & 46 \\
\hline Myoxocephalus quadricornis & 6 & $12.8 \pm 0.4$ & $-22.2 \pm 0.6$ & $3.8 \pm 0.1(5)$ & 47 \\
\hline \multicolumn{6}{|l|}{ Mammalia (caribou) } \\
\hline Rangifer tarandus & 1 & 2.0 & -25.1 & nd & 48 \\
\hline
\end{tabular}

$n$ number of samples analyzed, $n d$ not determined

signature in turn reflects approximate $\delta^{15} \mathrm{~N}$ and $\delta^{13} \mathrm{C}$ values of $0 \%$ and $-26.5 \%$ for tundra vegetation (Schell et al. 1984).

The lagoon grazer food web includes both pelagic and benthic organisms that ultimately rely on water column SPOM, from copepods to tube dwelling polychaetes (Fig. 3, upper panel.) First-level herbivores and key prey items such as calanoid copepods and zooplankton had $\delta^{13} \mathrm{C}$ and $\delta^{15} \mathrm{~N}$ values intermediate between benthic suspension feeders (hydrozoans, ascidians, and bryozoans) and carnivorous planktivores (ctenophores, arctic cod, and chaetognaths). At the other extreme, a number of benthic animals are clearly dependent on more ${ }^{15} \mathrm{~N}$-depleted sources of terrestrially derived organic matter (Fig. 3, bottom panel). These include deposit (or subsurface sediment) feeders such as various amphipods, nemerteans, sipunculids (peanut worms), the bivalve Yoldia, scaleworms (Polynoidae), and the gastropods Cylichna and Boreocingula.

Overall, our isotopic data reflect a community dominated by a variety of omnivorous benthic feeders that have intermediate values between the two lagoon end members
(Fig. 3, center panel). These omnivorous organisms include amphipods, polychaetes, gastropods, and bivalves; one predatory gastropod (Buccinum) and a carnivorous benthic fish (Lycodes) had the highest $\delta^{15} \mathrm{~N}$ values (over 14\%o) and the highest apparent trophic position of nearly all the benthic fauna studied.

Size differentiation also affected trophic position in some cases. Smaller $(<10 \mathrm{~mm})$ individuals of the amphipod Anonyx nugax had significantly lower $\delta^{15} \mathrm{~N}$ values $(9.5 \%$ ) than larger (>10 mm) A. nugax (13.3\%; Wilcoxon: $W=0, p<0.005)$ but no significant differences in $\delta^{13} \mathrm{C}$ values was observed between size groups ( $t$ test: $t=1.53, d f=10.89, p=0.15$ ). Following Turner et al. (2010), no overlap between groups was observed (Fig. 6), as reflected in the significant difference between niche widths of each group (mean distance to centroid $=0.81, P=0.014$ ).

In comparison to lagoon food webs, the isotopic composition of organisms collected on the coastal shelf of the Beaufort Sea (e.g., Camden Bay) are generally more ${ }^{13} \mathrm{C}$ enriched than their lagoon counterparts (Fig. 4), reflecting the higher $\delta^{13} \mathrm{C}$ 
Table $5 \delta^{13} \mathrm{C}$ and $\delta^{15} \mathrm{~N}$ values $($ mean $\pm \mathrm{SE})$ and molar $\mathrm{C}: \mathrm{N}$ ratios (mean $\pm \mathrm{SE}(n))$ of $\mathrm{BPOM}$ from sediments, SPOM, and biota collected on the nearshore shelf of the eastern Beaufort Sea in August 2008 and 2009 $n$ number of samples analyzed, $n d$ not determined

\begin{tabular}{|c|c|c|c|c|c|}
\hline Species & $n$ & $\delta^{15} \mathrm{~N}(\%)$ & $\delta^{13} \mathrm{C}(\%)$ & $\mathrm{C} / \mathrm{N}$ (moles/mole) & Fig. 4 Label \\
\hline \multicolumn{6}{|l|}{ Source of organic matter } \\
\hline Shelf BPOM & 63 & $3.4 \pm 0.1$ & $-25.4 \pm 0.1$ & nd & \\
\hline Shelf SPOM & 25 & $5.3 \pm 0.3$ & $-24.8 \pm 0.3$ & nd & \\
\hline \multicolumn{6}{|l|}{ Invertebrate consumers } \\
\hline \multicolumn{6}{|l|}{ Cephaloryncha } \\
\hline Priapulus caudatus & 1 & 12.5 & -20.9 & $4.6(1)$ & A \\
\hline \multicolumn{6}{|l|}{ Nemertea } \\
\hline Nemertean & 13 & $13.0 \pm 0.7$ & $-21.8 \pm 0.5$ & $5.0 \pm 0.2(11)$ & $\mathrm{B}$ \\
\hline \multicolumn{6}{|l|}{ Annelida } \\
\hline \multicolumn{6}{|l|}{ Polychaeta } \\
\hline Maldane sarsi & 40 & $11.2 \pm 0.2$ & $-22.5 \pm 0.1$ & $6.3 \pm 0.1(40)$ & $\mathrm{C}$ \\
\hline Sabellidae & 3 & $10.0 \pm 1.4$ & $-24.2 \pm 0.4$ & $5.6 \pm 0.1(3)$ & $\mathrm{D}$ \\
\hline \multicolumn{6}{|l|}{ Mollusca } \\
\hline \multicolumn{6}{|l|}{ Bivalvia } \\
\hline Liocyma fluctuosa & 7 & $7.6 \pm 0.3$ & $-23.7 \pm 0.5$ & $6.8 \pm 0.4(7)$ & $\mathrm{E}$ \\
\hline Macoma calcarea & 21 & $7.7 \pm 0.2$ & $-24.0 \pm 0.3$ & $7.6 \pm 0.4(18)$ & $\mathrm{F}$ \\
\hline \multicolumn{6}{|l|}{ Gastropoda } \\
\hline Neptunea heros & 2 & $12.1 \pm 0.5$ & $-20.4 \pm 0.2$ & $4.6(1)$ & G \\
\hline \multicolumn{6}{|l|}{ Arthropoda } \\
\hline \multicolumn{6}{|l|}{ Crustacea } \\
\hline Calanoid copepods & 17 & $9.8 \pm 0.2$ & $-24.7 \pm 0.3$ & $6.2 \pm 0.4(15)$ & $\mathrm{H}$ \\
\hline Mysis sp. & 3 & $10.4 \pm 0.5$ & $-21.9 \pm 0.4$ & $4.4 \pm 0.6(2)$ & I \\
\hline Pandalus sp. & 2 & $13.8 \pm 0.4$ & $-20.6 \pm 0.7$ & $3.7(1)$ & $\mathrm{J}$ \\
\hline Saduria entomon & 12 & $8.6 \pm 1.0$ & $-23.1 \pm 0.5$ & $7.4 \pm 0.8(3)$ & $\mathrm{K}$ \\
\hline \multicolumn{6}{|l|}{ Vertebrate consumers } \\
\hline \multicolumn{6}{|l|}{ Vertebrata } \\
\hline \multicolumn{6}{|l|}{ Osteichthyes } \\
\hline Boreogadus saida & 8 & $14.7 \pm 0.5$ & $-21.4 \pm 0.2$ & $3.9 \pm 0.2(8)$ & $\mathrm{L}$ \\
\hline $\begin{array}{c}\text { Coregonus autumnalis } \\
\text { (arctic cisco, } 15 \mathrm{~cm} \text { ) }\end{array}$ & 3 & $11.5 \pm 1.1$ & $-23.0 \pm 0.5$ & $4.3 \pm 0.1(3)$ & M \\
\hline Liparis sp. & 1 & 15.0 & -20.8 & $3.7(1)$ & $\mathrm{N}$ \\
\hline \multicolumn{6}{|l|}{ Mammalia (bearded seal) } \\
\hline Erignathus barbatus & 1 & 15.6 & -17.5 & $4.0(1)$ & $\mathrm{O}$ \\
\hline
\end{tabular}

value of shelf SPOM compared to lagoon SPOM (-24.8\%o and $-27.4 \%$, respectively). A similar scale of difference is seen with respect to $\delta^{15} \mathrm{~N}$ values. We found $\delta^{15} \mathrm{~N}$ values of arctic cod averaged $14.7 \%$ and $12.2 \%$ for shelf and lagoon collected specimens, respectively. The $2.5 \%$ difference nearly matches the difference in lagoon and shelf SPOM of 2.3\%o (Tables 4 and 5). Consequently, despite the relatively large difference in $\delta^{15} \mathrm{~N}$ values between shelf and lagoon habitats, it is reasonable to conclude that arctic cod occupy similar trophic levels in both ecosystems.

Trophic level determinations, using a nitrogen isotopic fractionation factor of $3.4 \%$, were assigned for nearly all the biota for which we had isotopic data (Table 6). These analyses indicate four trophic levels in lagoons, mainly driven by the presence of a diverse and opportunistic benthic fauna whose top benthic predators included the large priapulid worm Priapulus caudatus, the shell boring gastropod Euspira pallida, large $(>10 \mathrm{~mm})$ Anonyx nugax amphipods, three benthic fishes, and the predatory gastropod Buccinum. Beaufort shelf food webs also are comprised of four trophic levels from SPOM to arctic cod $(\mathrm{TL}=3.8)$. The trophic level of the bearded seal, Erignathus barbatus (4.0), reflects its predominant diet of epibenthic animals, including bivalves, gastropods, crustaceans, and fish (Lowry et al. 1980; Hjelset et al. 1999).

\section{Discussion}

The results of this work, along with other observations in a variety of other studies over the past three decades, provides 

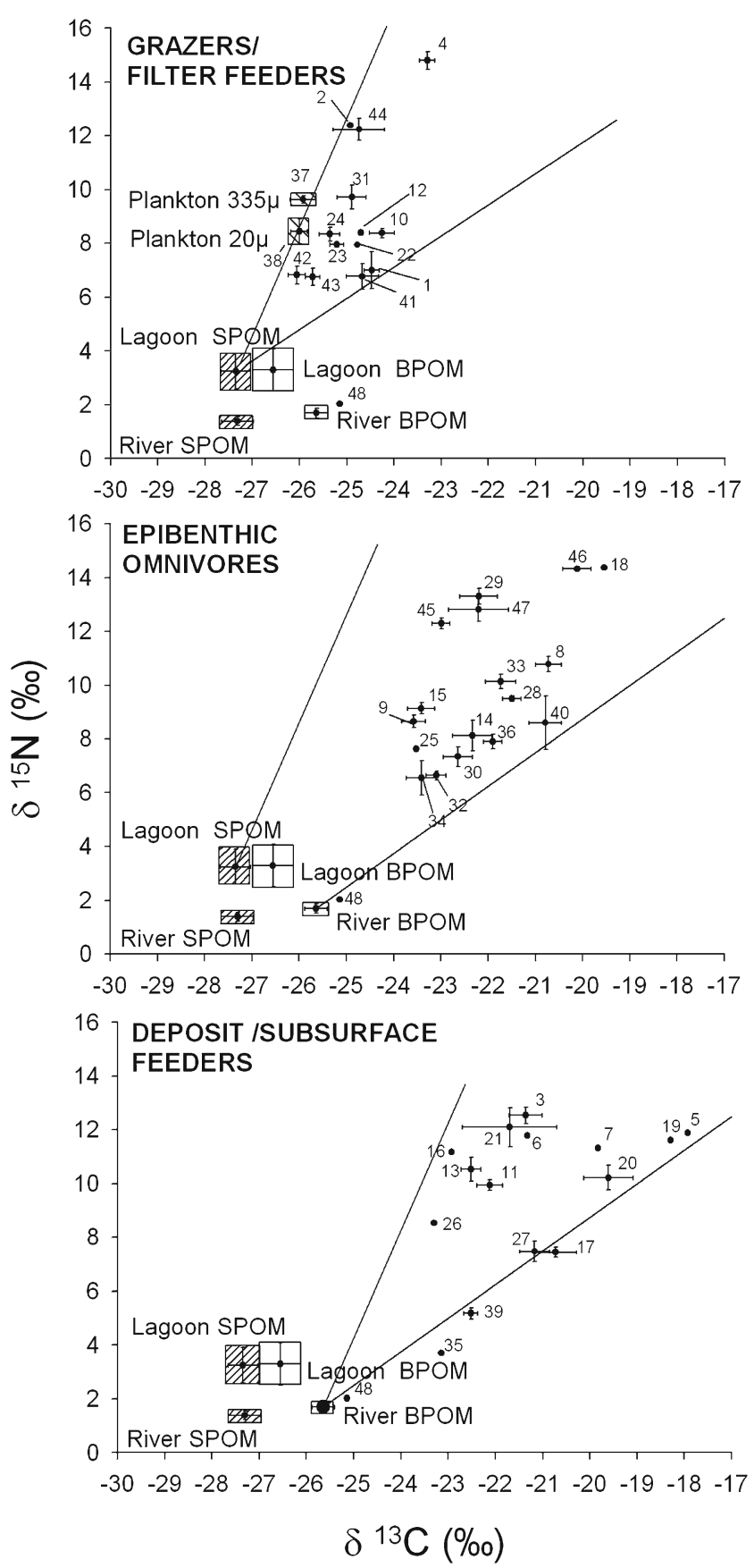

Fig. 3 Biplot of $\delta^{13} \mathrm{C}$ vs. $\delta^{15} \mathrm{~N}$ values for primary and secondary consumers collected in eastern Beaufort Sea estuarine lagoons. Consumers were grouped according to known feeding guilds. Numbers refer to specific species or groups as denoted in Table 4. Lines correspond to trophic increases of $+1.0 \%$ in $\delta^{13} \mathrm{C}$ and $+4.0 \%$ in $\delta^{15} \mathrm{~N}$ and of $+2.0 \%$ and $+2.5 \%$ in $\delta^{13} \mathrm{C}$ and $\delta^{15} \mathrm{~N}$ per trophic level based on known isotopic enrichments for consumers reported from the western arctic (see "Materials and Methods" section for details)

compelling evidence for a significant role that terrestrial carbon plays in subsidizing the productivity of estuarine lagoons of the eastern Alaska Beaufort Sea. Particulate organic matter in the lagoons, both on the seabed and on the bottom, is of terrestrial origin, based upon carbon and

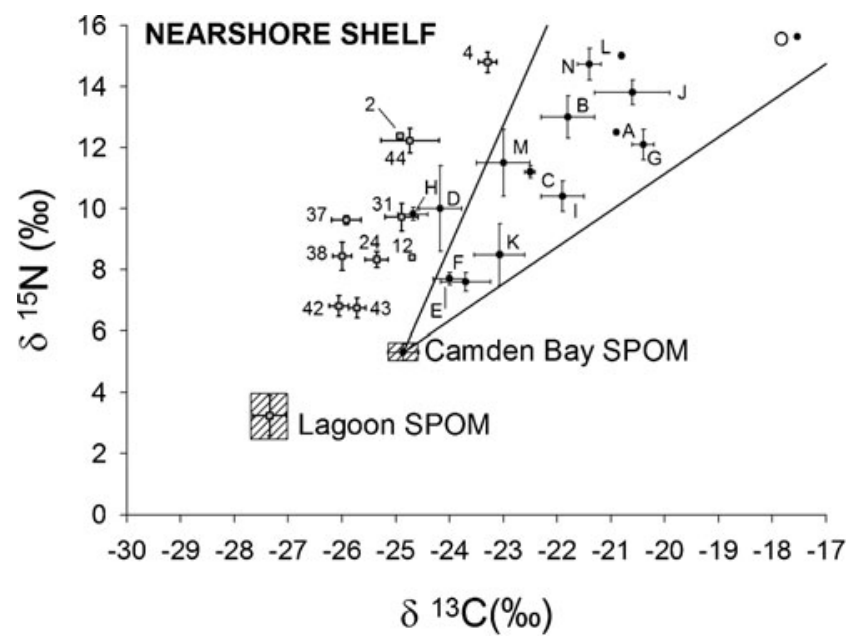

Fig. 4 Biplot of $\delta^{13} \mathrm{C}$ vs. $\delta^{15} \mathrm{~N}$ values for primary and secondary consumers collected on the nearshore shelf of the Beaufort Sea (denoted by letters, see Table 5) with lagoon grazers included for comparison (denoted by numbers, see Table 4). Lines correspond to trophic increases of $+1.0 \%$ in $\delta^{13} \mathrm{C}$ and $+4.0 \%$ in $\delta^{15} \mathrm{~N}$ and of $+2.0 \%$ and $+2.5 \%$ in $\delta^{13} \mathrm{C}$ and $\delta^{15} \mathrm{~N}$ per trophic level (see Fig. 3)

nitrogen isotope signatures. These sources of terrestrial carbon are assimilated, to a measureable extent, in consumer tissues. In addition, our measurements of benthic community structure reflect systems that are at least as productive, if not more than the adjacent nearshore shelf. The biomass and abundance of infaunal organisms in Demarcation Bay exceeds the levels expected for this shelf area based on a compilation of benthic biomass surveys performed by a variety of researchers on the inner shelf (summarized in Dunton et al. 2005). While this higher-than-expected productivity has been recognized with respect to its importance to waterfowl and anadromous fishes (Craig 1984; Craig et al. 1984), except for a handful of studies that are three decades old, there has been little progress

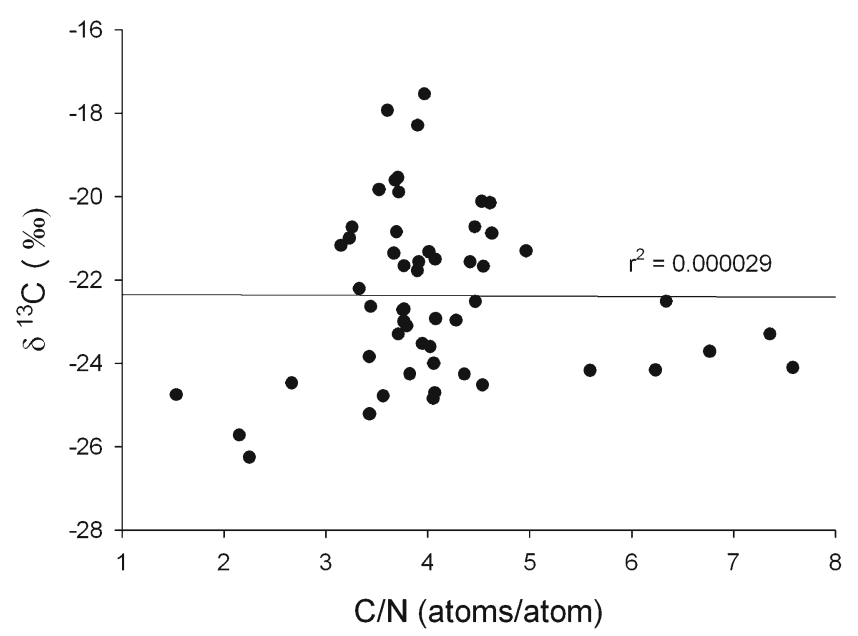

Fig. 5 Relationship between $\mathrm{C} / \mathrm{N}$ ratio and $\delta^{13} \mathrm{C}$ for marine fauna collected in the eastern Alaska Beaufort Sea (data from Tables 4 and 5; $n=55, r=0.005, P=0.98$ ) 


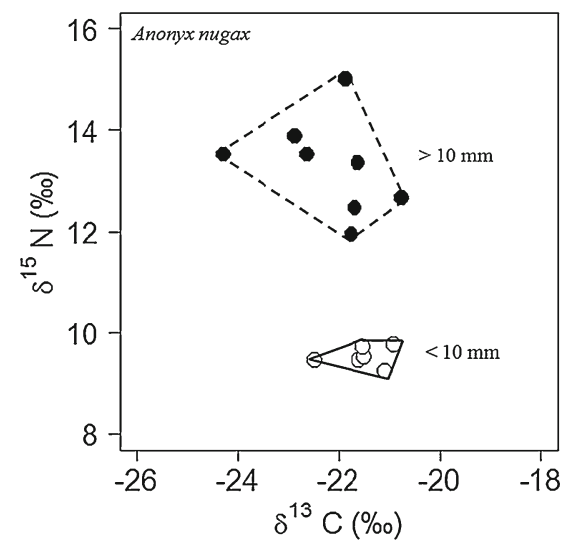

Fig. 6 The isotopic differences between large $(>10 \mathrm{~mm})$ and small $(<10 \mathrm{~mm})$ individuals of the amphipod $A$. nugax. The isotopic space occupied by large individuals with a mixed diet $(n=8$, filled circles, dashed outline) is distinct from that of small immature individuals ( $n=6$, open circles, solid outline) that feed at a lower trophic level

in our understanding of ecological structure and food webs in these coastal lagoons.

\section{The Biology and Hydrography of Coastal Lagoons}

Benthic infauna living within these lagoons are limited in mobility and therefore subjected to changes in physical processes common to all estuaries such as sedimentation, resuspension events, and advection which affect seasonal nutrient and recruitment fluxes, and ultimately, biological processes (Montagna and Kalke 1992). Benthic fauna inhabiting the shallow $(<2 \mathrm{~m})$ lagoons of the Beaufort Sea are further subject to the additional stresses of ice scour during winter months when fast ice often freezes to the bottom followed by erosion when large pulses of river water enter the lagoon during breakup in early summer (Jorgensen et al. 1999). For these reasons, benthic populations in these estuaries are composed of particularly well-adapted, shortlived species characterized by rapid growth and high reproduction levels (Emmett et al. 2000) that can survive the large salinity fluctuations that are associated with spring run-off.

Deeper lagoons and bays contain more established benthic populations that are not as commonly affected by ice gouging, but are affected by the input of organic matter. Our measurements showed that benthic infaunal abundance in Demarcation Bay (mean water depth, $4 \mathrm{~m}$ ) exceeds the levels measured in an adjacent coastal shelf area in Camden Bay (mean water depth, $34 \mathrm{~m}$ ), yet biomass measurements are similar between the two (Table 7). This pattern of low nearshore benthic biomass has been observed elsewhere. For example, at Prudhoe Bay, further west in the Beaufort Sea than our focused study area, Feder and Schamel (1976) found an increase in species diversity, abundance and biomass as distances offshore increased, which they attributed to ice and wave related forces affecting the stability of a
Table 6 Approximate trophic levels of biota collected for isotopic analysis within the estuarine lagoons of the eastern Beaufort Sea. Trophic calculations were based on a fractionation factor of $3.4 \%$ using lagoon SPOM (for grazers and filter feeders) and lagoon BPOM (for benthic omnivores and deposit feeders)

\begin{tabular}{|c|c|c|}
\hline & Organisms & $\begin{array}{l}\text { Trophic } \\
\text { level }\end{array}$ \\
\hline Sources of organic matter & $\begin{array}{l}\text { SPOM, BPOM, } \\
\text { phytoplankton }\end{array}$ & \\
\hline \multicolumn{3}{|l|}{ Primary consumers } \\
\hline \multirow[t]{6}{*}{ Grazers and filter feeders } & Alcyonidium disciforme & 2.1 \\
\hline & Eucratea loricata & 2.1 \\
\hline & Molgula griffthsii & 2.1 \\
\hline & Obelia longissima & 2.2 \\
\hline & Astarte borealis & 2.4 \\
\hline & Cyrtodaria kurriana & 2.4 \\
\hline \multirow[t]{7}{*}{ Benthic omnivores } & Pontoporeia femorata & 1.6 \\
\hline & Diastylis sp. & 2.0 \\
\hline & Gammarus setosus & 2.0 \\
\hline & Atylus carinatus & 2.2 \\
\hline & Macoma sp. & 2.3 \\
\hline & Mysis sp. & 2.4 \\
\hline & Spio filicornis & 2.4 \\
\hline \multirow[t]{3}{*}{ Deposit/subsurface feeders } & Monoculodes sp. & 1.1 \\
\hline & Boreocingula martini & 2.2 \\
\hline & Yoldia myalis & 2.2 \\
\hline \multicolumn{3}{|l|}{ Secondary consumers } \\
\hline \multirow[t]{3}{*}{ Benthic omnivores } & Anonyx nugax $(<10 \mathrm{~mm})$ & 2.8 \\
\hline & Cylichna occulta & 3.0 \\
\hline & Polynoidae (scaleworms) & 3.1 \\
\hline \multirow[t]{4}{*}{ Deposit/subsurface feeders } & Travisia forbesii & 3.3 \\
\hline & Cryptonatica affinis & 3.3 \\
\hline & Nephtys sp. & 3.4 \\
\hline & Nemertea & 3.5 \\
\hline Benthic predators & Coregonus autumnalis $^{\mathrm{a}}$ & 2.8 \\
\hline \multicolumn{3}{|l|}{ Tertiary consumers } \\
\hline \multirow[t]{5}{*}{ Pelagic carnivores } & Boreogadus saida & 3.7 \\
\hline & Boreogadus saida $^{\mathrm{a}}$ & 3.8 \\
\hline & Ctenophore & 3.8 \\
\hline & Erignathus barbatus $^{\mathrm{a}}$ & 4.0 \\
\hline & Sagitta sp. (chaetognaths) & 4.5 \\
\hline \multirow[t]{8}{*}{ Benthic predators } & Euspira pallida & 3.6 \\
\hline & Lumpenus fabricii & 3.6 \\
\hline & Liparis sp. $^{\mathrm{a}}$ & 3.9 \\
\hline & Priapulus caudatus & 3.7 \\
\hline & Myoxocephalus quadricornis & 3.8 \\
\hline & Anonyx nugax $(>10 \mathrm{~mm})$ & 3.9 \\
\hline & Lycodes $\mathrm{sp}$ & 4.2 \\
\hline & Buccinum sp. & 4.3 \\
\hline
\end{tabular}

${ }^{a}$ For comparison, trophic levels of vertebrate animals collected outside of lagoons on the nearshore shelf (calculated using Camden Bay SPOM) 
Table 7 A comparison of infaunal biomass and abundance (means \pm SE) on the Beaufort Sea nearshore shelf (Camden Bay) and in an estuarine lagoon (Demarcation Bay)

\begin{tabular}{|c|c|c|}
\hline Parameter & $\begin{array}{l}\text { Coastal shelf } \\
\text { Camden Bay }\end{array}$ & $\begin{array}{l}\text { Estuarine lagoon } \\
\text { Demarcation Bay }\end{array}$ \\
\hline Depth (m) & $34 \pm 0.43$ & $4 \pm 0.13$ \\
\hline Number of stations & 74 & 8 \\
\hline \multicolumn{3}{|l|}{ Infauna } \\
\hline Number of taxa & 177 & 48 \\
\hline Biomass $\left(\mathrm{g} \mathrm{m}^{-2}\right)$ & $47 \pm 11.3$ & $35 \pm 3.1$ \\
\hline Abundance $\left(\mathrm{n} \mathrm{m}^{-2}\right)$ & $385 \pm 43$ & $951 \pm 88$ \\
\hline \multicolumn{3}{|l|}{ Community structure } \\
\hline Margalef: species richness & $1.47-5.60$ & $1.58-3.93$ \\
\hline Shannon-Wiener: diversity & $1.68-3.35$ & $2.02-2.96$ \\
\hline Pielou: species evenness & $0.89-1.00$ & $0.92-0.98$ \\
\hline
\end{tabular}

Indices of community structure are station ranges within each system. Camden Bay data from Dunton et al. (2009)

shallow benthos. They also reported a relatively low species count (38 species) in Prudhoe Bay itself, which they attributed to low salinities. In the Kara Sea, Jorgensen et al. (1999) found that benthic biomass along the nearshore shelf was also lower than under full marine conditions, again reflecting the proportionately high volume of fresh water entering the coastal system (McClelland et al. 2011).

With respect to the water column, a study in the adjacent Mackenzie River estuary revealed that during summer there were two spatially separated plankton communities: (1) an offshore marine community associated with high phytoplankton production and populated with copepods, hydromedusae, and ctenophores and (2) an estuarine community associated with high levels of dissolved organic carbon, bacterial activity, and numerous amphipods (Parsons et al. 1988). Further west from the direct influence of the Mackenzie River, mixing of these two assemblages is apparent in Demarcation Bay, which receives inputs of marine SPOM along with river SPOM that contributes a substantial fraction of benthic detritus.

Based on results of earlier studies, other lagoons along the eastern Beaufort Sea coast may be as equally productive. Griffiths et al. (1977) used Ekman grabs in Kaktovik Lagoon in August 1975 at depths ranging from 2 to $4 \mathrm{~m}$ and found infauna abundances to range from 654 to 5,352 individuals per square meter, mainly dominated by crustaceans and annelids. No quantitative benthic data were collected by Griffiths et al. (1977) in Demarcation Bay, but in that estuary they reported a salinity of 11 at $10^{\circ} \mathrm{C}$ (compared to $13-20$ and $4-7^{\circ} \mathrm{C}$ during the same period in Kaktovik Lagoon) while collecting a variety of fish in gillnets (arctic char, arctic cisco, least cisco, grayling, and fourhorn sculpin).
Terrestrial Linkages to Estuarine Food Webs in Arctic Lagoons

Terrestrial organic matter inputs to the Arctic Ocean have long been considered a minor resource supporting microbial and metazoan communities. Interestingly, it was the pioneering isotopic work by Schell (1983) that initially focused on the role of terrestrial carbon as a potential food source in the northern Alaska coastal system that led to the development of the current paradigm. Schell (1983) noted that POC delivered to the coastal waters was prebomb and free of radiocarbon, but he found no evidence of old carbon in marine consumers, leading him to conclude that terrestrial sources of carbon are not incorporated into marine food webs. In other estuarine systems, there is ample evidence for the incorporation of terrestrially-derived organic matter into coastal marine food webs (Table 8).

We conclude that our study and other recent work indicate that terrestrial inputs may actually be a significant resource after all in arctic coastal waters. This means that arctic estuaries share this characteristic with lower latitude estuarine and coastal food webs (e.g., Table 8). Much of this other recent evidence is centered on dissolved organic carbon (DOC) contributions from rivers to the Arctic Ocean, which are quantitatively far greater than POC inputs (Gordeev et al. 1996; Lobbes et al. 2000; Dittmar and Kattner 2003). However DOC is disproportionately young and radiocarbon rich (Benner et al. 2004; Raymond et al. 2007), particularly that delivered during the spring freshet, which is more labile than that delivered at other times of the year (Holmes et al. 2008). The observation that significant fractions of DOC are apparently lost through photo-oxidation or bacterial consumption during the transit from major river mouths to offshore Arctic waters (e.g., Cooper et al. 2005) is additional evidence for a warranted re-evaluation of Schell's (1983) conclusion.

The results presented here are not unequivocal, but our isotopic measurements provide strong evidence that terrestrially-derived organic matter is assimilated and incorporated into consumer tissue, especially epibenthic crustaceans (mysids and amphipods) and molluscs, and deposit feeding molluscs and polychaetes. These species represent a major fraction of the lagoon community, both in terms of abundance and in biomass as demonstrated in this study, as well as previous work (Griffiths et al. 1977; Craig et al. 1984). According to the trophic food web studies conducted by Craig et al. (1984), mysids and amphipods are a clear favored prey item by fish (particularly arctic cod and various anadromous species) and birds. Furthermore, the average number of mysids and amphipods in the lagoon sediments far exceeds their numbers in the water column by 25 to 200 times (Griffiths and Dillinger 1981). The benthos is clearly a "hot spot" of concentrated preferred prey items for higher trophic levels in arctic lagoons. 
Table 8 POM source isotopic signatures in studies documenting the utilization of terrestrial sources of organic matter by key consumers in estuarine and coastal food webs throughout the world

\begin{tabular}{|c|c|c|c|c|}
\hline \multirow[t]{2}{*}{ Location } & \multicolumn{2}{|c|}{ POM source signatures } & \multirow{2}{*}{$\begin{array}{l}\text { Benthic consumer link from terrestrial } \\
\text { POM to higher trophic levels }\end{array}$} & \multirow[t]{2}{*}{ Reference } \\
\hline & Terrestrial $(\%)$ & Marine (\%) & & \\
\hline \multicolumn{5}{|c|}{ Eastern Australia } \\
\hline$\delta^{13} \mathrm{C}$ & -26.0 & -21.0 & Crabs & Connolly et al. (2009) \\
\hline$\delta^{15} \mathrm{~N}$ & 8.0 & 3.0 & & \\
\hline \multicolumn{5}{|c|}{ Miya Estuary, Japan } \\
\hline$\delta^{13} \mathrm{C}$ & -25.5 & -18.9 & Bivalves & Kasai et al. (2004) \\
\hline$\delta^{15} \mathrm{~N}$ & 0.6 & 9.0 & & \\
\hline \multicolumn{5}{|c|}{ NW Mediterranean } \\
\hline$\delta^{13} \mathrm{C}$ & -26.1 & -22.4 & Deposit feeding polychaetes & Darnaude et al. (2004) \\
\hline$\delta^{15} \mathrm{~N}$ & 3.5 & 2.3 & & \\
\hline \multicolumn{5}{|c|}{ York River Estuary, Virginia } \\
\hline$\delta^{13} \mathrm{C}$ & -25.9 & -23.5 & Adult chironomids & Hoffman et al. (2008) \\
\hline$\delta^{15} \mathrm{~N}$ & 4.2 & 9.9 & & \\
\hline \multicolumn{5}{|c|}{ Fjordland, NZ } \\
\hline$\delta^{13} \mathrm{C}$ & -29.0 & -21.3 & $\begin{array}{l}\text { Deposit feeding polychaetes and } \\
\text { Echinocardium }\end{array}$ & McLeod and Wing (2009) \\
\hline$\delta^{15} \mathrm{~N}$ & -1.4 & 6.6 & & \\
\hline \multicolumn{5}{|c|}{ Yura River, Japan } \\
\hline$\delta^{13} \mathrm{C}$ & -28.2 & -22.2 & $\begin{array}{l}\text { Deposit feeding polychaetes } \\
\text { (Neanthes) and bivalves }\end{array}$ & Antonio et al. (2010) \\
\hline$\delta^{15} \mathrm{~N}$ & 6.0 & 5.8 & & \\
\hline \multicolumn{5}{|c|}{ Plymouth, South Devon, UK } \\
\hline$\delta^{13} \mathrm{C}$ & -26.3 & -17.3 & Oligochaetes & Attrill et al. (2009) \\
\hline$\delta^{15} \mathrm{~N}$ & 4.2 & 9.3 & & \\
\hline
\end{tabular}

Assimilation of terrestrial organic detritus by lower trophic level consumers were based on consumer and source isotopic values for terrestrial and marine end members made on varying temporal scales

Our isotopic data also confirmed the presence of niche shifts between size classes in arctic amphipods that reflect ontogenetic changes between juvenile and adult life history stages (Legezynska 2008; Hammerschlag-Peyer et al. 2011). Amphipods, but particularly the genus Anonyx are largely known as voracious epibenthic scavengers that are highly omnivorous (Macdonald et al. 2010). In this study, A. nugax larger than $10 \mathrm{~mm}$ were classified as being one trophic level higher than smaller A. nugax, based upon significantly ( $p<$ $0.0001)$ higher $\delta^{15} \mathrm{~N}$ values. In addition to significant differences in niche width, each group's convex hull remained distinct with no overlap of individuals (Fig. 6). Based on the similar carbon isotopic ratios for both the small and large size classes $(-21.5 \%$ and $-22.2 \%$, respectively), but the shift in $\delta^{15} \mathrm{~N}$ values $(9.5-13.3 \%$ ), it is apparent that smaller individuals of $A$. nugax are feeding opportunistically at lower trophic levels on prey that are largely dependent on BPOM, while larger $(>10 \mathrm{~mm})$ individuals have graduated to a considerably more mixed diet that may include carrion as well as detritus, fish larvae, and small crustaceans (Legezynska 2008). Another amphipod, Gammarus setosus, is known for its unusual ability to digest peat, based on laboratory studies (Schneider and Koch 1979). This ability likely explains the $\delta^{15} \mathrm{~N}$ value for $G$. setosus, which was lowest (6.6\%) of all epibenthic omnivores (Table 4 and Fig. 3).

A majority of the consumers in this study exhibited an opportunistic feeding strategy as reflected in their omnivorous behavior as detritovores, and this is similar to other arctic systems (e.g., Iken et al. 2010). Trophic ${ }^{13} \mathrm{C}$ enrichment becomes progressively greater as dependence on deposit feeding increases (Fig. 3, bottom panel), with many organisms lying on the line of minimum slope (1.25), meaning the carbon isotopic fractionation associated with trophic levels is at a maximum. This likely reflects the increasing importance of microbial degradation and colonization of buried organic matter that is ingested by deposit feeders, which rapidly results in an enrichment of $\delta^{13} \mathrm{C}$ values in the combined microbial-detrital pool. This suggests that there is a strong link between the microbial and metazoan food webs rather than a direct pathway for terrestrial organic matter incorporation into first level consumers since very few organisms can assimilate terrestrial matter directly (Cividanes 
et al. 2002), with the possible exception of G. setosus (noted above). Another possible carbon resource are benthic microalgae, which are known to contribute to the productivity of arctic shelves (Grebmeier et al. 2006), but previous studies indicate that their $\delta^{13} \mathrm{C}$ values lie between $-17.6 \%$ and $-12.1 \%$, much heavier than nearly all the fauna we analyzed (Incze et al. 1982; Couch 1989; Riera and Richard 1999).

The isotopic separation between lagoon and Beaufort nearshore shelf planktivores (Fig. 4) suggests that lagoon SPOM, with its corresponding terrestrial signal is becoming incorporated into marine food webs. Sabellid suspension feeding polychaetes, mysids, and arctic cod, all exhibit distinctively ${ }^{15} \mathrm{~N}$ and ${ }^{13} \mathrm{C}$ depleted isotopic signatures in lagoons compared to the shelf (the ${ }^{13} \mathrm{C}$ signal is the same for mysids). One notable exception are calanoid copepods, which show no difference between lagoons and the shelf, but unlike mysids and amphipods, these copepods are not residents of lagoons, and we think they were likely advected into the lagoons from the arctic shelf. Mysids are the main diet for arctic cod (Craig et al. 1984), but cod are apparently consuming both mysids and copepods in lagoons, but only mysids offshore (based on $\delta^{15} \mathrm{~N}$ and $\delta^{13} \mathrm{C}$ values for consumer and prey). The distinct difference in cod isotopic signatures led Dunton et al. (2006) to conclude that cod assimilated at least half of its carbon from terrestrial sources, which seems reasonable based on the depleted $\delta^{15} \mathrm{~N}$ and $\delta^{13} \mathrm{C}$ values of other planktivores. Phytoplankton may contribute to the depleted $\delta^{13} \mathrm{C}$ values of lagoon SPOM through (1) their smaller cell sizes in estuarine settings, which has predictable consequences for greater ${ }^{13} \mathrm{C}$ fractionation (producing isotopically lighter cells) because of smaller surface areas (Korb et al. 1996) and (2) because dissolved inorganic carbon (DIC) will reflect riverine sources, DIC incorporated by photosynthesis is also isotopically lighter (Coffin and Cifuentes 1999).

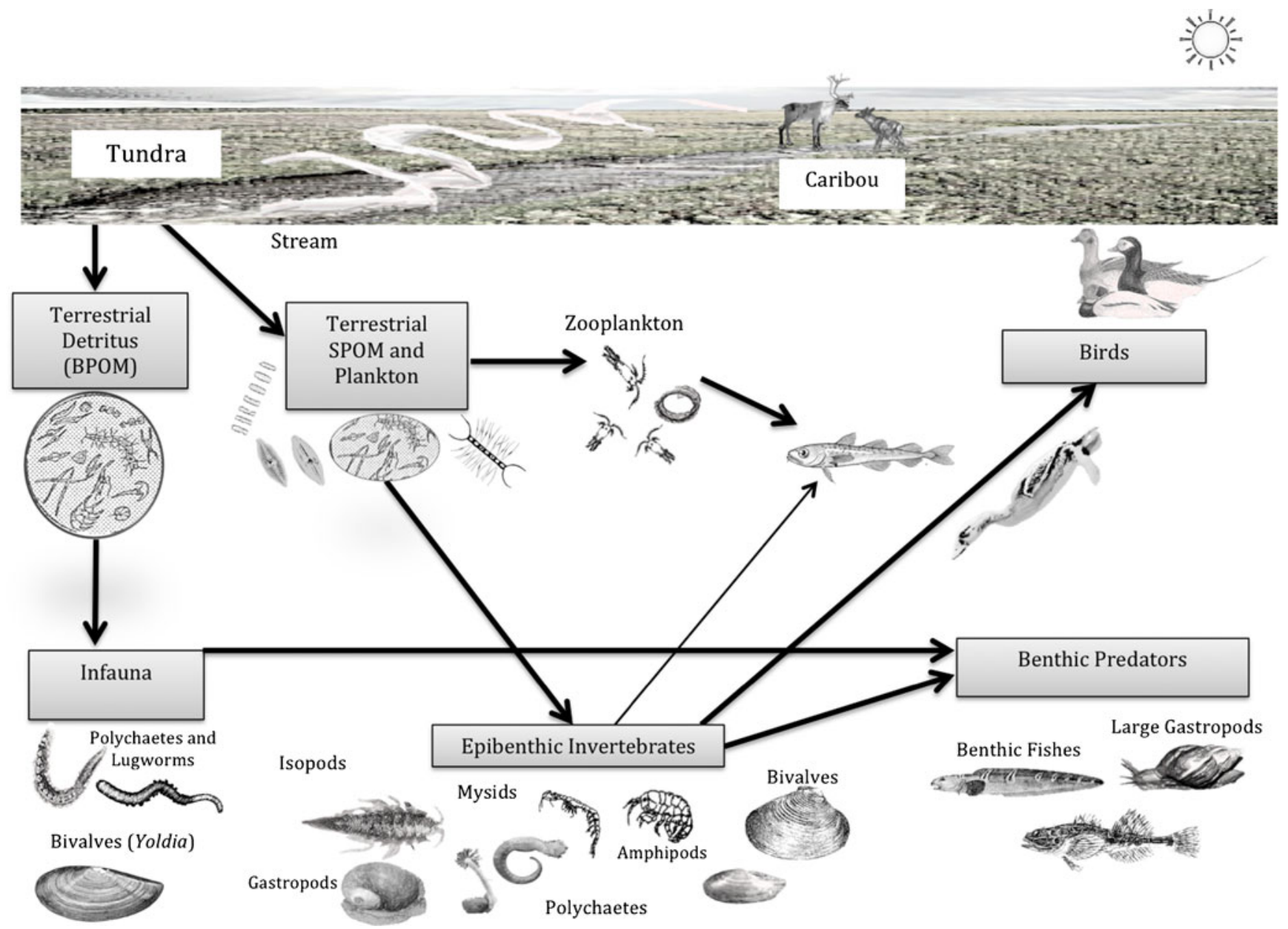

Fig. 7 A depiction of a high arctic estuarine lagoon food web. The high abundance and abundance of benthic biota are unique features of these relatively warmer summer systems that receive both autochthonous (phytoplankton) and allochthonous (terrestrial) inputs of carbon. Arrows show direction of energy transfer. For arctic cod, which feed on prey in both the water column and benthos, the linkage to pelagic sources of energy is slightly stronger based on available isotope data. The diversity of the benthic fauna reflects a resilient ecosystem that provides critical habitat for migrating waterfowl and nursery grounds for arctic cod, a critical prey item for seals and anadromous fishes on the inner shelf 
Animal migrations are a factor to consider in any stable isotope food web study, but our results are focused mainly on epibenthic and subsurface invertebrates and three species of benthic fish that do not migrate significantly. For arctic cod, we provide clear isotopic evidence that even these highly motile species may not migrate sufficiently to confuse the organic material signal present in lagoons. In addition, Hobson (2008) reports carbon isotope turnover times for muscle tissue are on the order of 150 days which well exceeds the summer open-water period in arctic lagoons. Based on the sampling time in late summer, following the productive period following ice melt in the spring, we feel that the isotopic values of the organisms collected in the lagoons likely reflect their diets since the spring freshet. Future winter sampling through the ice will help to verify the dependence of these fauna on terrestrial organic matter.

Our data demonstrate a terrestrial carbon subsidy (Fig. 7) to an otherwise oligotrophic lagoon ecosystem characterized by relatively clear estuarine waters (Table 1). In situ pelagic primary production is low, owing to extremely low inorganic-N concentrations (Table 2), so summer open-water chlorophyll levels along the coast and shelf provide no significant autochthonous source of production (Dunton et al. 2009). Consequently, terrestrial sources of organic matter provide a food resource for omnivorous consumers that contribute to benthic infaunal diversity and abundance to support both pelagic and detrital based food webs. Most importantly, the high diversity in these systems provide a degree of trophic redundancy and community resilience, critical habitat features to support upper trophic level organisms, such as waterfowl. Physical export of key prey species from these lagoons (mysids, amphipods, and arctic cod) also provide valuable resources for the large migrating bird and fish populations along the Alaska Beaufort Sea coastline (Connors 1984; Gallaway and Fechhelm 2000).

\section{Implications of a Changing Climate}

Although annual river discharge to the Arctic Ocean has increased by an average of $\sim 7 \mathrm{~km}^{3}$ each year over the 1964 2000 time period, the increase is not consistent for all areas (McClelland et al. 2006). On the arctic coast of Alaska, glacially-fed runoff from the Brooks Range to the eastern Beaufort Sea coast is in decline, and the small alpine glaciers in the Brooks Range are projected to disappear within the next 50 years (Nolan et al. 2011). The consequences for coastal lagoons will be significant in the loss of summer freshwater discharge and sediment input (although nutrients and dissolved organic carbon may increase with permafrost thaw). Significant effects on the ecology of these systems and their role as nursery habitats for migrating waterfowl are likely. When considered in the context of the summertime sea-ice cover loss, which decreased by $\sim 8 \%$ per decade over the
1979-2005 time period and the extreme minima observed in the past several years (Stroeve et al. 2008), it is an open question if the erosion and subsequent loss of coastal barrier islands will produce significant changes to the character of estuarine arctic lagoons. Related topics of uncertainty are whether ice algae make significant contributions of particulate and or dissolved organic matter to eastern Beaufort Sea estuarine lagoons, especially since warming is likely to affect ice cover in the lagoons differently than on the shelf. The answers to these questions will have important consequences on upper trophic levels, especially on bird and anadromous fish populations throughout the western arctic.

Acknowledgments The authors thank the Captains and crews of the Arctic Seal, Alpha Helix, and Proteus for their tremendous support in the field. Funding was provided by the Arctic Refuge, US Fish and Wildlife Service (project officer D. Payer) and Shell Exploration and Production Company, Alaska (project officer M. Macrander). We are extremely grateful to both for their continued support of our coastal research in Alaska. Our frequent overnight (and sleepless) field campaigns were greatly aided by support and comical relief provided by several field assistants, including D. Funk, N. McTigue, C. Strain, C. Villa, J. Dunton, and T. Dunton. Colleagues and native residents at Kaktovik kindly provided samples of fish and vertebrates from their research and subsistence harvesting activities across the Beaufort Sea coast. These include: W. Kayotuk (caribou and bearded seal), R. Fechhelm (arctic cisco and arctic cod), and H. Chenelot (arctic cod). Our lagoon studies and permits to work within the Arctic Refuge (2004, 2007, and 2008) were entirely supported by the US Fish and Wildlife Service, Arctic National Wildlife Refuge, under challenge Cost Share agreements with the University of Texas at Austin Marine Science Institute as facilitated by D. Payer and R. Voss. All samples collected in the lagoons, whether invertebrate or vertebrate, were treated following Institutional Animal Care and Use Committee protocols for respectful treatment of wild organisms to avoid or minimize distress. Special thanks to K. Coyle and N. Foster for their taxonomic expertise with crustaceans and molluscs, respectively; N. Haubenstock, P. Garlough, T. Howe, and K. Jackson for mass spectrometric analyses; D. Sjostrom, S. Wallace, and J. Stachelek for assistance with graphics, editing, and statistics. Finally, we thank two anonymous referees, V. von Biela, and A. Sousa for providing critically constructive suggestions that enabled us to make important improvements to earlier versions of this manuscript.

Open Access This article is distributed under the terms of the Creative Commons Attribution Noncommercial License which permits any noncommercial use, distribution, and reproduction in any medium, provided the original author(s) and source are credited.

\section{References}

Antonio, E.S., A. Kasai, M. Ueno, Y. Kurikawa, K. Tsuchiya, H. Toyohara, Y. Ishihi, H. Yokoyama, and Y. Yamashita. 2010. Consumption of terrestrial organic matter by estuarine molluscs determined by analysis of their stable isotopes and cellulase activity. Estuarine, Coastal and Shelf Science 86: 401-407.

Attrill, M.J., S.D. Rundle, A. Fraser, and M. Power. 2009. Oligochaetes as a possible entry route for terrigenous organic carbon into estuarine benthic food webs. Marine Ecology Progress Series 384: $147-157$.

Barnard, C., C. Martineau, J.J. Frenette, J.J. Dodson, and W.F. Vincent. 2006. Trophic position of zebra mussel veligers and their use of 
dissolved organic carbon. Limnology and Oceanography 51: $1473-1484$.

Benner, R., B. Benitez-Nelson, K. Kaiser, and R.M.W. Amon. 2004. Export of young terrigenous dissolved organic carbon from rivers to the Arctic Ocean. Geophysical Research Letters 31: L05305. doi:10.1029/2003GL019251.

Brown, S.C. 2006. Arctic wings: birds of the Arctic national wildlife refuge. Mountaineers Books. Seattle: Manomet Center for Conservation Sciences.

Carey, A.G., P.H. Scott, and K.R. Walters. 1984. Distributional ecology of shallow southwestern Beaufort Sea (Arctic Ocean) bivalve mollusca. Marine Ecology Progress Series 17: 125-134.

Cividanes, S., M. Incera, and J. Lopez. 2002. Temporal variability in the biochemical composition of sedimentary organic matter in an intertidal flat of the Galician coast (NW Spain). Oceanologica Acta 25: 1-12.

Coffin, R.B., and L.A. Cifuentes. 1999. Stable isotope analysis of carbon cycling in the Perdido Estuary, Florida. Estuaries 22: 917-926.

Connolly, R.M., T.A. Schlacher, and T.F. Gaston. 2009. Stable isotope evidence for trophic subsidy of coastal benthic fisheries by river discharge plumes off small estuaries. Marine Biology Research 5: 164-171.

Connors, P.G. 1984. Ecology of shorebirds in the Alaskan Beaufort littoral zone. In The Alaskan Beaufort Sea: ecosystems and environments, ed. P.W. Barnes, D.M. Schell, and E. Reimnitz, 403-416. Orlando: Academic.

Cooper, L.W., J.M. Grebmeier, I.L. Larsen, V.G. Egorov, C. Theodorakis, H.P. Kelly, and J.R. Lovvorn. 2002. Seasonal variation in sedimentation of organic materials in the St. Lawrence Island polynya region, Bering Sea. Marine Ecology Progress Series 226: 13-26.

Cooper, L.W., R. Benner, J.W. McClelland, B.J. Peterson, R.M. Holmes, P.A. Raymond, D.A. Hansell, J.M. Grebmeier, and L.A. Codispoti. 2005. Linkages among runoff, dissolved organic carbon, and the stable isotope composition of seawater and other water mass indicators in the Arctic Ocean. Journal of Geophysical ResearchBiogeosciences 110: G02013. doi:1029/2005JG000031.

Cooper, L.W., C. Lalande, R.S. Pirtle-Levy, I.L. Larsen, and J.M. Grebmeier. 2009. Seasonal and decadal shifts in particulate organic matter processing and sedimentation in the Bering Strait Shelf Region. Deep-Sea Research Part II 56: 1316-1325.

Couch, C.A. 1989. Carbon and nitrogen stable isotopes of meiobenthos and their food resources. Estuarine and Coastal Shelf Science 28: 433-441.

Craig, P.C. 1984. Fish use of coastal waters of the Alaskan Beaufort Sea-a review. Transactions of the American Fisheries Society 113: 265-282.

Craig, P.C., W.B. Griffiths, S.R. Johnson, and D. Schell. 1984. Trophic dynamics in an arctic lagoon. In The Alaskan Beaufort Sea: ecosystems and environments, ed. P.W. Barnes, D.M. Schell, and E. Reimnitz, 347-380. Orlando: Academic.

Darnaude, A.M., C. Salen-Picard, N.V.C. Polunin, and M.L. HarmelinVivien. 2004. Trophodynamic linkage between river runoff and coastal fishery yield elucidated by stable isotope data in the Gulf of Lions (NW Mediterranean). Oecologia 138: 325-332.

Dittmar, T., and G. Kattner. 2003. The biogeochemistry of the river and shelf ecosystem of the Arctic Ocean: a review. Marine Chemistry 83: $103-120$.

Dunton, K.H. 2001. $\delta^{15} \mathrm{~N}$ and $\delta^{13} \mathrm{C}$ measurements of Antarctic peninsula fauna: trophic relationships and assimilation of benthic seaweeds. American Zoologist 41: 99-112.

Dunton, K.H., and D.M. Schell. 1987. Dependence of consumers on macroalgal (Laminaria solidungula) carbon in an arctic kelp community: $\delta^{13} \mathrm{C}$ evidence. Marine Biology 93: 615-625.

Dunton, K.H., and S.V. Schonberg. 2000. The benthic faunal assemblage of the Boulder Patch kelp community. In The natural history of an Arctic oil field: development and the biota, ed. J.C. Truett and S.R. Johnson, 371-397. Boston: Academic.

Dunton, K.H., and S.V. Schonberg. 2006. Barter Island to Demarcation Bay: a preliminary benthic survey of Arctic coastal lagoons. Fairbanks: Final Report to USF\&WS, Arctic Refuge.

Dunton, K.H., S.M. Saupe, A.N. Golikov, D.M. Schell, and S.V. Schonberg. 1989. Trophic relationships and isotopic gradients among arctic and subarctic marine fauna. Marine Ecology Progress Series 56: 89-97.

Dunton, K.H., J.L. Goodall, S.V. Schonberg, J.M. Grebmeier, and D.R. Maidment. 2005. Multi-decadal synthesis of benthic-pelagic coupling in the western arctic: role of cross-shelf advective processes. Deep-Sea Research Part II 52: 3462-3477.

Dunton, K.H., T. Weingartner, and E.C. Carmack. 2006. The nearshore western Beaufort Sea ecosystem: circulation and importance of terrestrial carbon in arctic coastal food webs. Progress in Oceanography 71: 362-378.

Dunton, K.H., S.V. Schonberg, and D.W. Funk. 2009. Interannual and spatial variability in light attenuation: evidence from three decades of growth in the arctic kelp, Laminaria solidungula. In Smithsonian at the poles: contributions to international polar science, ed. Krupnick et al., 271-284. Washington: Smithsonian Institution Scholarly Press.

Dunton, K.H., S.V. Schonberg, and N. D. McTigue. 2009. Characterization of Benthic Habitats in Camden Bay (Sivulliq Prospect and Hammerhead Drill Sites), Beaufort Sea, Alaska. Anchorage: Final Report to Shell Exploration and Production Company, Alaska.

Emmett, R., R. Llanso, J. Newton, R. Thom, M. Hornberger, C. Morgan, C. Levings, A. Copping, and P. Fishman. 2000. Geographic signatures of North American West Coast estuaries. Estuaries 23: 765-792.

Feder, H. M. and D. Schamel. 1976. Shallow-water benthic fauna of Prudhoe Bay. Pages 329-359 in D. W. Hood and D. C. Burrell, editors. Assessment of the Arctic Marine Environment. Institute of Marine Science, University of Alaska.

Gallaway, B.J., and R.G. Fechhelm. 2000. Anadromous and amphidromous fishes. In The natural history of an Arctic oil field: development and the biota, ed. J.C. Truett and S.R. Johnson, 349-370. Boston: Academic.

Gordeev, V.V., J.M. Martin, I.S. Sidorov, and M.V. Sidorova. 1996. A reassessment of the Eurasian River input of water, sediment, major elements, and nutrients to the Arctic Ocean. American Journal of Science 296: 664-691.

Grebmeier, J.M., L.W. Cooper, H.M. Feder, and B.I. Sirenko. 2006. Ecosystem dynamics of the Pacific-influenced northern Bering, Chukchi, and East Siberian Seas. Progress in Oceanography 71: 331-361.

Griffiths, W.B., and R.E. Dillinger. 1981. Beaufort Sea barrier islandlagoon ecological process studies: the invertebrates. Environmental Assessment of the Alaskan Continental Shelf 8: 1-359.

Griffiths, W.B., J.K. Den Beste, and P.C. Craig. 1977. Fisheries investigations in a coastal lagoon region of the Beaufort Sea (Kaktovik Lagoon, Alaska). Arctic Gas Biological Report Series 40(2): 1190.

Hammerschlag-Peyer, C.M., L.A. Yeager, M.S. Araújo, and C.A. Layman. 2011. A hypothesis-testing framework for studies investigating ontogenetic niche shifts using stable isotope ratios. PLOS ONE 6(11): e27104.

Hjelset, A.M., M. Andersen, I. Gjertz, C. Lydersen, and B. Gulliksen. 1999. Feeding habits of bearded seals (Erignathus barbatus) from the Svalbard area, Norway. Polar Biology 21(3): 186-193.

Hobson, K.A. 2008. Applying isotopic methods to tracking animal movements. In Tracking animal migration with stable isotopes, ed. K.A. Hobson and L.I. Wassenaar, 45-78. London: Elsevier. 
Hoffman, J.C., D.A. Bronk, and J.E. Olney. 2008. Organic matter sources supporting lower food web production in the tidal freshwater portion of the York River Estuary, Virginia. Estuaries and Coasts 31: 898-911.

Holmes, R.M., J.W. McClelland, P.A. Raymond, B.B. Frazer, B.J. Peterson, and M. Stieglitz. 2008. Lability of DOC transported by Alaskan rivers to the Arctic Ocean. Geophysical Research Letters 35: L03402. doi:10.1029/2007GL032837.

Iken, K., B. Bluhm, and K. Dunton. 2010. Benthic food-web structure under differing water mass properties in the southern Chukchi Sea. Deep-Sea Research Part II 57: 71-85.

Incze, L.S., L.M. Mayer, E.B. Sherr, and S.A. Macko. 1982. Carbon inputs to bivalve molluscs; a comparison of two estuaries. Canadian Journal of Fisheries and Aquatic Sciences 39: 1348-1352.

Johnson, S.R., and W.J. Richardson. 1981. Beaufort Sea barrier islandlagoon ecological process studies: birds. Environmental Assessment of the Alaskan Continental Shelf Final Report 7: 109-383.

Jorgensen, L.L., T.H. Pearson, N.A. Anisimova, B. Gulliksen, S. Dahle, S.G. Denisenko, and G.G. Matishov. 1999. Environmental influences on benthic fauna associations of the Kara Sea (Arctic Russia). Polar Biology 22: 395-416.

Kasai, A., H. Horie, and W. Sakamoto. 2004. Selection of food sources by Ruditapes philippinarum and Mactra veneriformis (Bivalva: Mollusca) determined from stable isotope analysis. Fisheries Science 70: 11-20.

Korb, R.E., J.A. Raven, A.M. Johnston, and J.W. Leftley. 1996. Effects of cell size and specific growth rate on stable carbon isotope discrimination by two species of marine diatom. Marine Ecology Progress Series 143: 283-288.

Legezynska, J. 2008. Food resource partitioning among Arctic sublittoral lysianassoid amphipods in summer. Polar Biology 31: $663-670$.

Lobbes, J.M., H.P. Fitznar, and G. Kattner. 2000. Biogeochemical characteristics of dissolved and particulate organic matter in Russian rivers entering the Arctic Ocean. Geochimica et Cosmochimica Acta 64: 2973-2983.

Lovvorn, J.R., L.W. Cooper, M.L. Brooks, C.C. De Ruyck, J.K. Bump, and J.M. Grebmeier. 2005. Organic matter pathways to zooplankton and benthos under pack ice in late winter and open water in late summer in the north-central Bering Sea. Marine Ecology Progress Series 291: 135-150.

Lowry, L.F., K.J. Frost, and J.J. Burns. 1980. Feeding of bearded seals in the Bering and Chukchi Seas and trophic interaction with Pacific walruses. Arctic 33(2): 330-342.

Macdonald, R.W., E. Sakshaug, and R. Stein. 2004. The Arctic Ocean: modern status and recent climate change. In The organic carbon cycle in the Arctic Ocean, ed. R. Stein and R.W. Macdonald, 621. Berlin: Springer.

Macdonald, T.A., B.J. Burd, V.I. Macdonald, and A. van Roodselaar. 2010. Taxonomic and feeding guild classification for the marine benthic macroinvertebrates of the Strait of Georgia, British Columbia. Canadian Technical Report of Fisheries and Aquatic Sciences. 2874: iv +63 p.

McClelland, J.W., S.J. Déry, B.J. Peterson, R.M. Holmes, and E.F. Wood. 2006. A pan-arctic evaluation of changes in river discharge during the latter half of the 20th century. Geophysical Research Letters 33: L06715. doi:10.1029/2006GL025753.

McClelland, J., R.M. Holmes, K.H. Dunton, and R.W. MacDonald. 2011. The Arctic Ocean estuary. Estuaries and Coasts. doi:10.1007/s12237-010-9357-3.

McLeod, R.J., and S.R. Wing. 2009. Strong pathways for incorporation of terrestrially derived organic matter into benthic communities. Estuarine, Coastal and Shelf Science 82: 645-653.

Montagna, P.A., and R.D. Kalke. 1992. The effect of fresh-water inflow on meiofaunal and macrofaunal populations in the Guadalupe and Nueces estuaries, Texas. Estuaries 15: 307-326.
Morata, N., P.E. Renaud, S. Brugel, K.A. Hobson, and B.J. Johnson. 2008. Spatial and seasonal variations in the pelagic-benthic coupling of the southeastern Beaufort Sea revealed by sedimentary biomarkers. Marine Ecology Progress Series 371(47-63): 2008.

Naidu, A.S., L.W. Cooper, B.P. Finney, R.W. Macdonald, C. Alexander, and I.P. Semiletov. 2000. Organic carbon isotope ratios $\left(\delta^{13} \mathrm{C}\right)$ of Arctic Amerasian continental shelf sediments. International Journal of Earth Sciences 89: 522-532.

Nolan, M., R. Churchwell, J. M. Adams, J. McClelland, K. Tape, S. Kendall, A. et al. 2011. Predicting the impact of glacier loss on fish, birds, floodplains, and estuaries in the Arctic National Wildlife Refuge. Pages 49-54 in C. N. Medley et al., editors. Observing, Studying and Managing for Change. Proceedings of the Fourth Interagency Conference on Research in the Watersheds: U.S. Geological Survey Scientific Investigations Report 20115169

Norton, D., and G. Weller. 1984. The Beaufort Sea: background, history and perspective. In The Alaskan Beaufort Sea: ecosystems and environments, ed. P.W. Barnes, D.M. Schell, and E. Reimnitz, 3-19. Orlando: Academic.

Parsons, T.R., Y. Maita, and C.M. Lalli. 1984. A manual of chemical and biological methods for seawater analysis. Oxford: Pergamon.

Parsons, T.R., D.G. Webb, H. Dovey, R. Haigh, M. Lawrence, and G.E. Hopky. 1988. Production studies in the Mackenzie River-Beaufort Sea estuary. Polar Biology 8: 235-239.

Parsons, T.R., D.G. Webb, B.E. Rokeby, M. Lawrence, G.E. Hopky, and D.B. Chiperzak. 1989. Autotrophic and heterotrophic production in the Mackenzie River/Beaufort Sea estuary. Polar Biology 9: 261-266.

Post, D.M. 2002. Using stable isotopes to estimate trophic position: models, methods, and assumptions. Ecology 83: 703-718.

Post, D.M., C.A. Layman, D.A. Arrington, G. Takimoto, J. Quattrochi, and C.G. Montana. 2007. Getting to the fat of the matter: models, methods and assumptions for dealing with lipids in stable isotope analyses. Oecologia 152: 179-189.

Rau, G.H., T. Takahashi, D.J. Des Marais, D.J. Repeta, and J.H. Martin. 1992. The relationship between $\delta^{13} \mathrm{C}$ of organic matter and $\left[\mathrm{CO}_{2}(\mathrm{aq})\right]$ in ocean surface water: data from a JGOFS site in the northeast Atlantic Ocean and a model. Geochimica et Cosmochimica Acta 56: 1413-1419.

Raymond, P.A., J.W. McClelland, R.M. Holmes, A.V. Zhulidov, K. Mull, B.J. Peterson, R.G. Striegl, G.R. Aiken, and T.Y. Gurtovaya. 2007. Flux and age of dissolved organic carbon exported to the Arctic Ocean: a carbon isotopic study of the five largest arctic rivers. Global Biogeochem. Cycles 21: GB4011. doi:4010.1029/2007GB002934.

Riera, P., and P. Richard. 1999. Determination of food sources for benthic invertebrates in a salt marsh (Aiguillon Bay, France) by carbon and nitrogen stable isotopes: importance of locally produced surfaces. Marine Ecology Progress Series 187: 301307.

Sandberg, J., A. Andersson, S. Johansson, and J. Wikner. 2004. Pelagic food web structure and carbon budget in the northern Baltic Sea: potential importance of terrigenous carbon. Marine Ecology Progress Series 268: 13-29.

Saupe, S.M., D.M. Schell, and W.B. Griffiths. 1989. Carbon-isotope ratio gradients in western arctic zooplankton. Marine Biology 103: 427-432.

Schell, D.M. 1983. Carbon-13 and carbon-14 abundances in Alaskan aquatic organisms: delayed production from peat in arctic food webs. Science 219: 1068-1071.

Schell, D., J.C. Zieman, D.M. Parrish, K.H. Dunton, and E. Brown. 1984. Foodweb and nutrient dynamics in nearshore Alaska Beaufort Sea waters. Environmental Assessment of the Alaskan Continental Shelf 25: 327-499. 
Schell, D.M., S.M. Saupe, and N. Haubenstock. 1989. Bowhead whale (Balaena mysitcetus) growth and feeding as estimated by $\delta^{13} \mathrm{C}$ techniques. Marine Biology 103: 433-443.

Schell, D.M., B.A. Barnett, and K.A. Vinette. 1998. Carbon and nitrogen isotope ratios in zooplankton of the Bering, Chukchi and Beaufort seas. Marine Ecology Progress Series 162: 11-23.

Schneider, D. and H. Koch. 1979. Trophic relationships of the arctic shallow water marine ecosystem. Pages 503-542 in A.C. Broad et al. (eds). Environmental Assessment of Selected Habitats in the Beaufort and Chukchi Littoral System. Environmental Assessment of the Alaskan Continental Shelf, Annual Reports 3:361-542.

Stroeve, J., A. Frei, J. McCreight, and D. Ghatak. 2008. Arctic sea-ice variability revisited. In: J. Jacka (eds). Annals of Glaciology 48:71-81.

Trefry, J.H., R.D. Rember, R.P. Trocine, and J.S. Brown. 2003. Trace metals in sediments near offshore oil exploration and production sites in the Alaskan Arctic. Environmental Geology 45: 149-160.
Turner, T.F., M.L. Collyer, and T.J. Krabbenhoft. 2010. A general hypothesis-testing framework for stable isotope ratios in ecological studies. Ecology 91: 2227-2233.

Vander Zanden, M.J., and J.B. Rasmussen. 2001. Variation in delta $\mathrm{N}-15$ and delta $\mathrm{C}-13$ trophic fractionation: implications for aquatic food web studies. Limnology and Oceanography 46: 2061-2066

von Biela, V.R., C.E. Zimmerman, and L.L. Moulton. 2011. Long-term increases in young-of-the year growth of Arctic cisco Coregonus autumnalis and environmental influences. Journal of Fish Biology 78: 39-56.

Wada, E., M. Terazaki, Y. Kabaya, and T. Nemoto. $1987 .{ }^{15} \mathrm{~N}$ and ${ }^{13} \mathrm{C}$ abundances in the Antarctic Ocean with emphasis on the biogeochemical structure of the food web. Deep-Sea Research 34: 829-841.

Winston, J.E. 1977. Feeding in marine bryozoans. In Biology of Bryozoans, ed. R.M. Woollacott and R.L. Zimmer, 233-271. New York: Academic. 